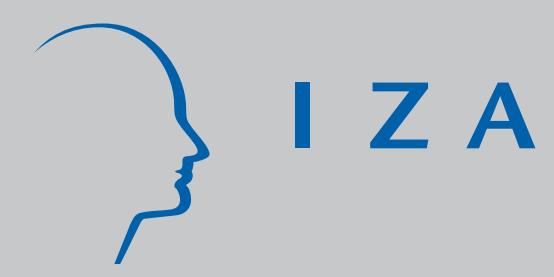

IZADP No. 1463

Self-Selection, Immigrant Public Finance Performance and Canadian Citizenship

Don J . DeVoretz

Sergiy Pivnenko

J anuary 2005 


\title{
Self-Selection, Immigrant Public Finance Performance and Canadian Citizenship
}

\author{
Don J. DeVoretz \\ RIIM, Simon Fraser University \\ and IZA Bonn \\ Sergiy Pivnenko \\ RIIM, Simon Fraser University
Discussion Paper No. 1463
January 2005

IZA

P.O. Box 7240

53072 Bonn

Germany

Phone: +49-228-3894-0

Fax: +49-228-3894-180

Email: iza@iza.org

\begin{abstract}
Any opinions expressed here are those of the author(s) and not those of the institute. Research disseminated by IZA may include views on policy, but the institute itself takes no institutional policy positions.

The Institute for the Study of Labor (IZA) in Bonn is a local and virtual international research center and a place of communication between science, politics and business. IZA is an independent nonprofit company supported by Deutsche Post World Net. The center is associated with the University of Bonn and offers a stimulating research environment through its research networks, research support, and visitors and doctoral programs. IZA engages in (i) original and internationally competitive research in all fields of labor economics, (ii) development of policy concepts, and (iii) dissemination of research results and concepts to the interested public.
\end{abstract}

IZA Discussion Papers often represent preliminary work and are circulated to encourage discussion. Citation of such a paper should account for its provisional character. A revised version may be available directly from the author. 
IZA Discussion Paper No. 1463

January 2005

\section{ABSTRACT \\ Self-Selection, Immigrant Public Finance Performance and Canadian Citizenship}

This paper consists of two parts focusing on the immigrant's decision to acquire Canadian citizenship, and her subsequent performance as a taxpayer and recipient of public finance transfers. Our results support the view that selectivity bias appears in Canadian immigrant citizenship decisions and varies by immigrant gender and source country groups. Our Oaxaca decomposition results demonstrated the importance of the human capital endowment in explaining selectivity corrected citizenship-non-citizenship earnings differences. Next, we confirmed the standard results that the naturalization decision is conditioned by the expected wage gain, level of education, marital status, age and presence of children. At the macro level, our study focused on the implications of Canadian citizenship for the lifetime public finance contributions by naturalized immigrants. All immigrants, regardless of their source country group and citizenship status, made a positive contribution to Canada's treasury circa 1996 over their life cycle. Naturalized citizens from OECD countries contributed the largest public finance transfers exceeding the corresponding value for the Canadian -born by more than $\$ 14,000$. In addition, naturalized citizens made higher net contributions than their non-citizen counterparts regardless of source country. The relatively poor public finance performance of non-citizens was explained by their lifetime low income and low tax payments.

JEL Classification: J61, J68, F22

Keywords: citizenship, immigration, public finance, Canada

Corresponding author:

Sergiy Pivnenko

Centre of Excellence: Immigration

Simon Fraser University

8888 University Drive

Burnaby, BC, V5 A 1 S6

Canada

Email: spivnenk@sfu.ca 


\section{Introduction}

DeVoretz and Pivnenko (2004b) demonstrated earlier that age, marital status, presence of children and wages of immigrants from poor countries (non-OECD) predicted immigrant ascension to Canadian citizenship. Immigrants from developed OECD countries were found to condition their citizenship decision only on their years of residence in Canada and their prospective earnings gain after citizenship. In addition, they found that a substantial economic impact derived from this ascension to Canadian citizenship. However, they concluded that selection into citizenship and the subsequent earnings outcome were not independent, and, thus, their reported econometric results may be biased. In particular their recognition that number of weeks worked (or earnings) and citizenship ascension may be endogenous led them to conclude that immigrants may experience positive self-selection. This observation, plus an expanded analysis including the labour market and public finance impacts derived from immigrant ascension to citizenship, motivated this paper.

\section{Literature}

The economic literature on citizenship primarily consists of two separate views. One view attempts to rationalize an immigrant's decision to acquire citizenship, and the other investigates the economic consequences of such a decision. The evidence on the determinants of acquiring citizenship remains highly controversial largely due to the specifics of the populations studied and the varying nature of the data used. While some authors (Kelley and McAllister, 1982; Portes and Mozo, 1985) insist on the importance of socio-economic variables, such as education, occupation and income, others (Bernard, 1936; Barkan and Khokhlov, 1980, Portes and Curtis, 1987) put forward cultural assimilation and demographic characteristics as the major determinants of an immigrant's naturalization decision. With the aid of 1980 U.S. Census micro data, Yang (1994) was the first to apply a cost-benefit framework to investigate the effects of individual characteristics and the socio-economic conditions of the immigrant's home and host country on the immigrant's citizenship decision. Yang's findings indicate that cultural integration plays a more important role than economic integration in the immigrant's naturalization decision. Age at immigration, marital status and the presence of children were among the demographic factors that increased the odds of an immigrant becoming a 
citizen. While the home country level of development proved to be a significant predictor of immigrant's naturalization decision, the availability of dual citizenship did not obtain the expected effect.

The other stream of studies ignores the economic rationale for becoming a citizen and addresses only the possible economic impacts derived from the immigrant ascending to citizenship. While Bratsberg et al. (2002) ignore the economic rationale for becoming a citizen, they do address the possible economic impact of immigrant citizenship in the United States labour market. Using a youth panel study, they find that immigrant ascension to citizenship alters the immigrants' occupational distribution and raises their earnings. Moreover, they argue that these effects are greater for immigrants from less developed countries. Scott (2004) found differential citizenship effects in Swedish labour market depending on the immigrant's source country. He also showed that, after controlling for education and years since immigration, in most cases the wage differential between naturalized citizens and non-citizens disappears or even becomes negative.

Other economic studies of citizenship are even more limited in scope since they mostly incorporate the citizenship affect in an ad hoc manner or as addendum to a larger study. Pivnenko and DeVoretz (2004) found a strong citizenship effect on Ukrainian immigrant earnings in Canada. Mata (1999) reports no evidence on the economic impact of Canadian citizenship on immigrant earnings after conducting a principal components analysis with 1996 Canadian data. In reviewing the economic outcomes of ChineseCanadian citizens who returned to Hong Kong, DeVoretz and Zhang (2004) found that citizens earned higher incomes than any other resident group in Hong-Kong. For his part, Bevelander (2000) reports that the log-odds of obtaining employment improved for those immigrants to Sweden who obtained citizenship in 1990. In addition, Bengston and Scott (forthcoming) reviewed the implications of citizenship on the use of Swedish disability benefits

We conclude from this brief literature survey that studies of citizenship ascension and its economic impact are fragmented and limited in scope. In addition, this literature review suggests that economic modeling appears particularly difficult because of demanding data requirements and a need to model strong institutional components affecting the labour market outcomes. 


\section{Stylized facts}

One long-term goal of Canadian immigration policy is to insure that the majority of its foreign-born arrivals become citizens. To this end, the current Canadian Ministry of Citizenship and Immigration performs both immigrant and citizenship selection functions. ${ }^{1}$ The process of citizenship acquisition is straightforward. In fact, the majority of foreign-born permanent immigrants to Canada are entitled to apply for citizenship after a three-year period of residency. Thus, the 1996 Census of Canada reports that $74.6 \%$ of Canada's foreign-born residents are citizens. Nonetheless, variations in acquisition of citizenship appear. Figure 1 portrays the important observation that there are differential rates of citizenship ascension by immigrants for each year in residence in Canada and by their country of origin.

As shown in Figure 1, after 10 years in residence, about 30\% of immigrants from non-OECD countries become Canadian citizens. After the $25^{\text {th }}$ year in residence, the process ends as the remaining stock of residents from developing countries (non-OECD) have largely acquired citizenship. ${ }^{2}$ Just the opposite picture emerges for immigrants from the OECD - Canada's traditional source countries in Western Europe and the United States. Here significant immigrant ascension to citizenship only appears after 25 years or more in residence.

\footnotetext{
${ }^{1}$ In the past, the Ministry of Immigration was merged with the Ministry of Justice, and, prior to that, with the Ministry of Manpower. Each reorganization reflected the perspective of the government in power on the outcomes of immigrants.

2 An unknown number of the original entry cohort could have disappeared after 25 years and this would produce an upward bias in the rate of citizenship acquisition.
} 
Figure 1: Ascention to Citizenship by Immigrants from OECD and non-OECD countries

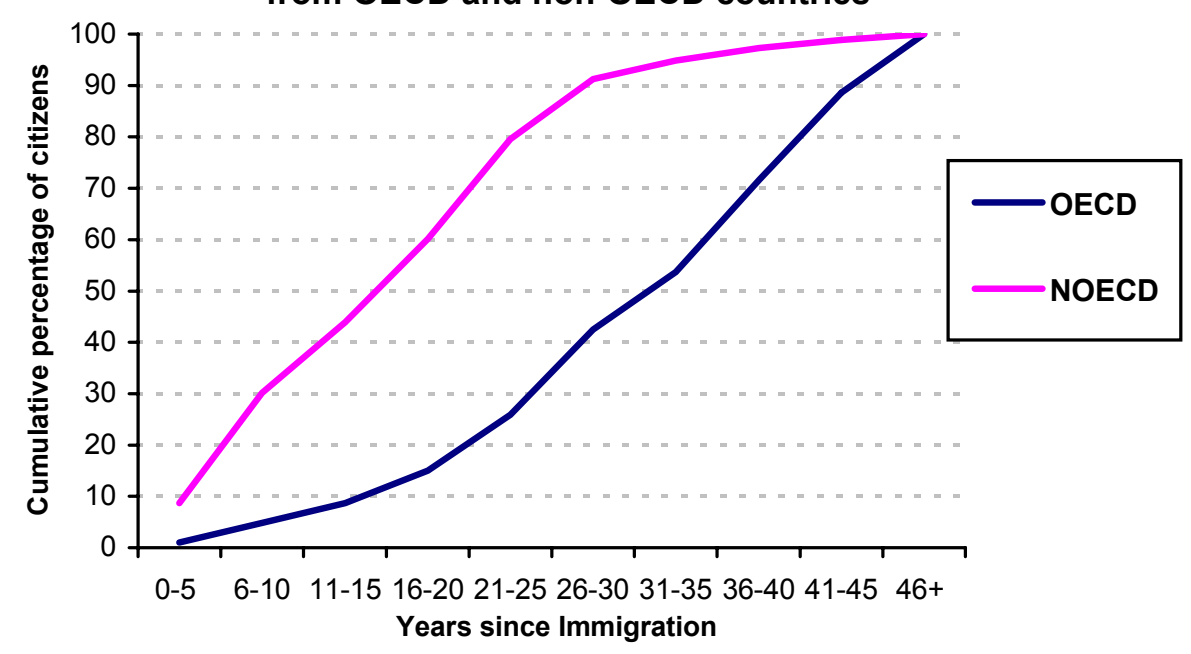

Source: 1996 Census of Canada

Even within Western Europe differential rates of ascension appear. For example, more than $68 \%$ of Polish immigrants in Canada had acquired citizenship whereas only 24 $\%$ of Dutch immigrants had become citizens. Finally, in 1996 over 17\% of all foreignborn residents reported dual citizenship, with the majority coming from Western Europe and the United States.

These simple stylized facts belie the degree of controversy that has arisen in Canada with respect to the economic implications of acquiring citizenship. In 2003 the Canadian Supreme Court upheld Canada's citizenship hiring preference for an array of federal government jobs, and ruled against an immigrant class action suit to recover damages from this alleged discrimination ${ }^{3}$. The plaintiffs argued that both job and earnings discrimination arose under the citizenship requirement since immigrants without citizenship were unable to practice their profession and enjoy the relatively high earnings from a federal position.

Given the literature reviewed and the arguments contained in DeVoretz and Pivnenko (2004b), we expect that, even after controlling for human capital, citizenship acquisition may still increase foreign-born earnings. Indeed naturalized citizens should face less labour market discrimination as perceived cultural differences disappear and

\footnotetext{
${ }^{3}$ The Court argued in the majority that, since there was no barrier to becoming a Canadian citizen, then inherently immigrants did not face discrimination, but just a waiting period applied to all.
} 
legal access to federal government jobs becomes greater. On the other hand, the decision to acquire citizenship could be motivated by this anticipated earnings premium, especially in professional occupations. Moreover, this motivation could differ by source country, with a greater effect being generated for foreign-born citizens from developing countries.

In sum, the relative ease of acquiring Canadian citizenship and the presumed earnings effect derived from that decision argue for a model that recognizes the simultaneity inherent in citizenship acquisition and economic outcomes.

\section{Data}

Both the legal process to obtain Canadian citizenship and our model design dictate data selection and variable definitions. In this study we select a population of immigrants from the 1996 Census of Canada Public Use Microdata Files (PUMF). In order to ensure that potentially naturalized citizens have met the time requirements to apply for Canadian citizenship, we restrict our sample to immigrants who landed prior to 1993. ${ }^{4}$ Since our model focuses on the wage effect that may arise from citizenship acquisition by employed foreign-born workers, we would ideally like to have wage rate data. However, since our data source does not provide information on hourly wage rates, our regression analysis must be performed using the individual's annual wage or salary earned in 1995, controlled by weeks worked in that year. ${ }^{5}$ Also, any individual records reporting inconsistent observations on wage, salary income, or weeks worked, are excluded from our data set. ${ }^{6}$ Moreover, since we focus our analysis on employed, working-age immigrants, individuals over 65 and under 25 years are excluded from our data set.

Our model also dictates that the majority of the data used as explanatory variables are recoded as zero-one dummy variables. Marital status (MARRIED) is coded as a 1- for legally married, or 0 - otherwise. Next, we recoded the educational variable 'highest

\footnotetext{
${ }^{4}$ Landed immigrants must live in Canada for at least three of the four years preceding their citizenship application.

${ }^{5}$ Given the annual nature of our data, we must ignore the possibility that our wage data may contain earnings derived from overtime premiums, or that foreign-born residents may work at more than one job.

${ }^{6}$ That is, positive earnings for zero weeks or zero earnings for positive weeks. In addition, by restricting wage earnings to a minimum of $\$ 1,000$ we further cleaned our sample of those who reported hourly or weekly wages instead of annual earnings.
} 
degree earned' into a string of dummies indicating the acquisition of either a trades certificate or diploma (DIPL), bachelor degree (BACH), above bachelor (BACHPL, i.e. Masters or medical degrees) or an earned doctorate (PHD). Similarly, we transformed the occupational variable of the immigrant into a series of dummy variables representing professional (PROF), managerial (MANG) or a skilled (SKL) classification.

Based on the above definitions, Table 1 provides some stylized facts by immigrant source country and citizenship status. ${ }^{7}$ Since our earlier work indicated that citizenship acquisition might be a by-product of the level of development of the foreignborn Canadians' country of origin, we further divide our data into immigrants from OECD and non-OECD countries.

Table 1: Descriptive statistics for selected immigrant groups by country of origin and citizenship status.

\begin{tabular}{|c|c|c|c|c|c|c|c|c|}
\hline & \multicolumn{2}{|c|}{$\begin{array}{l}\text { OECD immigrants } \\
\qquad \mathrm{N}=21,945\end{array}$} & \multicolumn{2}{|c|}{$\begin{array}{c}\text { Non-OECD } \\
\text { immigrants } \\
\mathrm{N}=18,667\end{array}$} & \multicolumn{2}{|c|}{$\begin{array}{c}\text { Citizens } \\
\mathrm{N}=33,661\end{array}$} & \multicolumn{2}{|c|}{$\begin{array}{l}\text { Non-citizens } \\
\mathrm{N}=6,951\end{array}$} \\
\hline & Count & Percent & Count & Percent & Count & Percent & Count & Percent \\
\hline \multicolumn{9}{|l|}{ Age } \\
\hline $25<$ age $<36$ & 4172 & 19.01 & 5623 & 30.12 & 7605 & 22.59 & 2190 & 31.51 \\
\hline $35<$ age $<46$ & 5686 & 25.91 & 6109 & 32.73 & 9676 & 28.75 & 2119 & 30.48 \\
\hline $45<$ age $<56$ & 8000 & 36.45 & 4773 & 25.57 & 10933 & 32.48 & 1840 & 26.47 \\
\hline $55<$ age $<66$ & 4087 & 18.62 & 2162 & 11.58 & 5447 & 16.18 & 802 & 11.54 \\
\hline \multicolumn{9}{|l|}{ Marital status } \\
\hline Legally married & 17189 & 78.33 & 14320 & 76.71 & 26135 & 77.64 & 5374 & 77.31 \\
\hline Other & 4756 & 21.67 & 4347 & 23.29 & 7526 & 22.36 & 1577 & 22.69 \\
\hline \multicolumn{9}{|l|}{ Highest degree } \\
\hline $\mathrm{H} / \mathrm{S}$ or less & 10235 & 46.64 & 7775 & 41.65 & 14552 & 43.23 & 3458 & 49.75 \\
\hline Diploma & 7584 & 34.56 & 6009 & 32.19 & 11453 & 34.02 & 2140 & 30.79 \\
\hline Bachelor & 2241 & 10.21 & 3020 & 16.18 & 4467 & 13.27 & 794 & 11.42 \\
\hline Bachelor plus & 1483 & 6.76 & 1593 & 8.53 & 2627 & 7.80 & 449 & 6.46 \\
\hline Ph.D. & 402 & 1.83 & 270 & 1.45 & 562 & 1.67 & 110 & 1.58 \\
\hline \multicolumn{9}{|l|}{ Occupation } \\
\hline Unskilled & 8966 & 40.86 & 9785 & 52.42 & 15111 & 44.89 & 3640 & 52.37 \\
\hline Skilled & 5545 & 25.27 & 3523 & 18.87 & 7563 & 22.47 & 1505 & 21.65 \\
\hline Professional & 4836 & 22.04 & 3869 & 20.73 & 7476 & 22.21 & 1229 & 17.68 \\
\hline Managerial & 2598 & 11.84 & 1490 & 7.98 & 3511 & 10.43 & 577 & 8.30 \\
\hline \multicolumn{9}{|l|}{ Weeks worked } \\
\hline $0-25$ & 2062 & 9.40 & 2026 & 10.85 & 3261 & 9.69 & 827 & 11.90 \\
\hline $26-40$ & 2458 & 11.20 & 2344 & 12.56 & 3822 & 11.35 & 980 & 14.10 \\
\hline $41-52$ & 17425 & 79.40 & 14297 & 76.59 & 26578 & 78.96 & 5144 & 74.00 \\
\hline Wage earnings & \multicolumn{2}{|c|}{$\begin{array}{l}\text { Mean } \\
\$ 34,867\end{array}$} & \multicolumn{2}{|c|}{$\begin{array}{l}\text { Mean } \\
\$ 28,280\end{array}$} & \multicolumn{2}{|c|}{$\begin{array}{c}\text { Mean } \\
\$ 32,554 \\
\end{array}$} & \multicolumn{2}{|c|}{$\begin{array}{l}\text { Mean } \\
\$ 28,376\end{array}$} \\
\hline
\end{tabular}

Source: 1996 Census of Canada

\footnotetext{
${ }^{7}$ Since the available micro data file represented a 5\% censored sample of the 1996 Census of Canada, we were able to identify a limited number of source countries. The identified OECD countries include France, Germany, Greece, Italy, the Netherlands, Portugal, Spain, the United Kingdom, and the United States. Our sampled non-OECD countries include all African countries, the Caribbean, China (PRC), India, Latin America, Lebanon, the Philippines, Poland, the USSR, Vietnam, and Yugoslavia
} 
Given that we will employ a human capital model of earnings, next we focus our analysis on key socio-economic variables, and observe, except for marital status, substantial differences across immigrant groups, as defined by citizenship and source country. For example, the average age of foreign-born citizens, or of OECD immigrants, is greater than that of non-citizens, or non-OECD counterparts. Also, naturalized citizens are better educated than non-citizens ( $22.74 \%$ vs. $19.46 \%$ with a post-secondary degree) and fewer of them are in unskilled occupations (44.89\% vs. $52.37 \%$ for non-citizens). In contrast, non-OECD immigrants are more likely to have obtained a post-secondary degree $(26.16 \%$ vs. $18.8 \%)$ than OECD immigrants, but are more often employed in unskilled occupations (52.42\% vs. $40.86 \%)$ than OECD workers. Finally, on average citizens work more weeks, and more citizens are employed full-time (79\% vs. $74 \%$ ) than non-citizens. This combination of full-time employment and greater skill levels of foreign-born citizens contributes to higher annual wage earnings for citizens $(\$ 32,554)$ vs. non-citizens $(\$ 28,376)$.

This brief overview indicates that citizenship status is correlated with greater human capital endowments and more robust earning performances for Canadian immigrants.

\section{Model}

The empirical model specified here addresses the aforementioned selection bias that can occur when foreign-born workers sort themselves into citizenship status on the basis of unobserved factors that can also influence their resulting post-citizenship wages. A correction technique owing to Heckman will allow us to develop unbiased inferences about the earnings of the employed citizen and non-citizen immigrant populations. ${ }^{8}$

DeVoretz and Pivnenko (2004b) have already demonstrated that a significantly positive earnings effect derives from ascension to Canadian citizenship. In addition, they acknowledged the possibility that reverse causality can occur if the higher earnings observed among naturalized citizens influence the immigrant's decision to acquire

\footnotetext{
${ }^{8}$ However, as we will discuss later, the Heckman model is particularly sensitive to the choice of variables included in the selection function.
} 
Canadian citizenship. ${ }^{9}$ In other words, citizenship status (C), and the natural logarithm of citizen and non-citizen gross annual wages may be determined simultaneously. Thus, citizenship status may also be a function of the expected citizen/non-citizen wage differential, since immigrants incorporate the potential wage premium associated with citizenship status in their decision to become citizens. Following Heckman (1976) and Lee (1978) we estimate the outlined empirical model in order to account for this potential selection bias and the implied simultaneity:

$$
\begin{aligned}
& C_{i}=\alpha_{0}+\alpha_{1} X_{i}+\alpha_{2} Y_{i}+\alpha_{3} L W \hat{D} I F_{i}+\varepsilon_{i} \\
& \ln W_{i}=\beta_{0}+\beta_{1} X_{i}+\beta_{2} Z_{i}+\beta_{3} \lambda_{i}+v_{i}, \text { if } \mathrm{C}_{\mathrm{i}}=1 \\
& \ln W_{i}=\gamma_{0}+\gamma_{1} X_{i}+\gamma_{2} Z_{i}+\gamma_{3} \lambda_{i}+\tau_{i}, \text { if } \mathrm{C}_{\mathrm{i}}=0
\end{aligned}
$$

where

$\mathrm{C}_{\mathrm{i}}$ - binary variable indicating the immigrant's choice of citizenship status (1- citizen, 0 non-citizen);

$\mathrm{X}_{\mathrm{i}}$ - vector to represent the immigrant's human capital characteristics;

$\mathrm{Y}_{\mathrm{i}}$ - other determinants of citizenship status;

$\mathrm{Z}_{\mathrm{i}}$ - control variables in wage equation (such as occupational choice and weeks worked).

$\lambda_{i}=\frac{\phi\left(\hat{C}_{i}^{*}\right)}{\Phi\left(\hat{C}_{i}^{*}\right)}$ if $\mathrm{C}_{\mathrm{i}}=1$, or $\lambda_{i}=\frac{-\phi\left(\hat{C}_{i}^{*}\right)}{\left(1-\Phi\left(\hat{C}_{i}^{*}\right)\right)}$ if $\mathrm{C}_{\mathrm{i}}=0-$ selectivity variable (Inverse Mill's

Ratios for citizens and non-citizens respectively).

$L W \hat{D} I F_{i}$ - simulated citizen-non-citizen wage differential which equals the difference between the logarithms of:

i) observed and opportunity wages $\ln W_{i}-\left(\hat{\gamma}_{0}+\hat{\gamma}_{1} X_{i}+\hat{\gamma}_{2} Z_{i}+\hat{\gamma}_{3} \lambda_{i}\right)$ for citizens, or

ii) opportunity and observed wages $\left(\hat{\beta}_{0}+\hat{\beta}_{1} X_{i}+\hat{\beta}_{2} Z_{i}+\hat{\beta}_{3} \lambda_{i}\right)-\ln W_{i}$ for noncitizens $;^{10}$

In the first stage the selection equation is estimated by a maximum likelihood technique as an independent probit model to determine the decision to acquire Canadian

\footnotetext{
${ }^{9}$ Robinson and Tomes (1982) were the first to apply the Heckman correction in the migration context.

${ }^{10}$ Here we rationalize our assumption that an immigrant forms her citizenship premium expectations based on the observed performances of her counterparts with similar background but opposite citizenship status.
} 
citizenship. A vector of Inverse Mills Ratios (IMRs), estimated expected error, is then generated from the parameter estimates of the selection equation. The citizen's wage is observed only when the selection equation equals 1 (i.e., immigrant acquires citizenship) and its logarithm is then regressed on the explanatory variables and the vector of IMRs from the selection equation by ordinary least squares (OLS) method. Similarly we obtain OLS coefficients in non-citizen wage equation. Hence, in the second stage we rerun the regression with the estimated expected error included as an extra explanatory variable, removing the part of the error term correlated with the explanatory variable, and thus avoiding the suspected selection bias.

In order to generate the IMRs we use the reduced form of equation (1) that excludes wage differentials for the citizen/non-citizen workers. Then we incorporate the estimated lambdas into wage equations (2) and (3) and run an OLS procedure to estimate the selection bias corrected regressions coefficients. Next, we use the estimated coefficients for citizens (non-citizens) to forecast the opportunity wages for non-citizens (citizens). Finally, we estimate a probit equation (1) using the simulated citizen/noncitizen wage differentials.

\section{Empirical Results}

Wage earnings equation

The results for the earnings equations are presented in Table 2. At this point we must keep in mind that some of the model's estimated coefficients do not lend themselves to a straightforward interpretation. If a variable appears only in the wage equation, its coefficient can be simply interpreted as the marginal effect of a one-unit change in the variable that appears in this one equation. If, on the other hand, the variable appears in both the selection and wage equations, the coefficient in the outcome equation is affected by its presence in the selection equation as well. Table 2 shows the estimated coefficients derived from the earnings equations, implying that the indirect effects of age and education on the logarithm of wages are not shown in this table. 


\begin{tabular}{|c|c|c|c|c|c|c|}
\hline & \multicolumn{2}{|l|}{ All immigrants } & \multicolumn{2}{|c|}{ OECD immigrants } & \multicolumn{2}{|c|}{ Non-OECD immigrants } \\
\hline & Non-citizens & Citizens & Non-citizens & Citizens & Non-citizens & Citizens \\
\hline & \multicolumn{6}{|c|}{$\begin{array}{c}\text { Estimated OLS coefficients } \\
\text { (t-statistics) }\end{array}$} \\
\hline AGE & $\begin{array}{r}0.0573 \\
(6.72) \\
\end{array}$ & $\begin{array}{r}0.0798 \\
(19.34)\end{array}$ & $\begin{array}{r}0.0515 \\
(5.55) \\
\end{array}$ & $\begin{array}{r}0.0748 \\
(14.29) \\
\end{array}$ & $\begin{array}{r}0.0564 \\
(4.07) \\
\end{array}$ & $\begin{array}{r}0.0727 \\
(13.95) \\
\end{array}$ \\
\hline $\mathrm{AGE}^{2}$ & $\begin{array}{r}-0.0005 \\
(-5.29) \\
\end{array}$ & $\begin{array}{l}-0.0007 \\
(-19.52) \\
\end{array}$ & $\begin{array}{r}-0.0005 \\
(-4.72) \\
\end{array}$ & $\begin{array}{l}-0.0007 \\
(-14.98) \\
\end{array}$ & $\begin{array}{r}-0.0005 \\
(-3.43) \\
\end{array}$ & $\begin{array}{l}-0.0006 \\
(-12.17) \\
\end{array}$ \\
\hline FEMALE & $\begin{array}{l}-0.3899 \\
(-21.88) \\
\end{array}$ & $\begin{array}{l}-0.3468 \\
(-45.10) \\
\end{array}$ & $\begin{array}{l}-0.4594 \\
(-21.12) \\
\end{array}$ & $\begin{array}{l}-0.4368 \\
(-40.96) \\
\end{array}$ & $\begin{array}{r}-0.2752 \\
(-9.13) \\
\end{array}$ & $\begin{array}{l}-0.2566 \\
(-23.45) \\
\end{array}$ \\
\hline OFLANG & $\begin{array}{r}0.0837 \\
(2.30)\end{array}$ & $\begin{array}{r}0.1949 \\
(8.06) \\
\end{array}$ & $\begin{array}{r}-0.0634^{*} \\
(-1.24)\end{array}$ & $\begin{array}{r}0.0796^{*} \\
(1.77) \\
\end{array}$ & $\begin{array}{r}0.1423 \\
(2.79)\end{array}$ & $\begin{array}{r}0.2042 \\
(7.09) \\
\end{array}$ \\
\hline DIPL & $\begin{array}{r}0.1665 \\
(2.65) \\
\end{array}$ & $\begin{array}{r}0.2323 \\
(9.26) \\
\end{array}$ & $\begin{array}{r}0.0645 \\
(1.81) \\
\end{array}$ & $\begin{array}{r}0.1296 \\
(7.77) \\
\end{array}$ & $\begin{array}{r}0.2175 \\
(2.40) \\
\end{array}$ & $\begin{array}{r}0.2721 \\
(8.86) \\
\end{array}$ \\
\hline $\mathrm{BACH}$ & $\begin{array}{r}0.3316 \\
(3.75)\end{array}$ & $\begin{array}{r}0.3925 \\
(11.15)\end{array}$ & $\begin{array}{r}0.2248 \\
(5.12)\end{array}$ & $\begin{array}{r}0.3002 \\
(13.84)\end{array}$ & $\begin{array}{r}0.3239 \\
(3.08)\end{array}$ & $\begin{array}{l}0.3907 \\
(10.81)\end{array}$ \\
\hline BACHPL & $\begin{array}{r}0.3408 \\
(4.03)\end{array}$ & $\begin{array}{r}0.4380 \\
(13.10)\end{array}$ & $\begin{array}{r}0.3250 \\
(5.70)\end{array}$ & $\begin{array}{l}0.3804 \\
(14.11)\end{array}$ & $\begin{array}{r}0.2157 \\
(2.12)\end{array}$ & $\begin{array}{l}0.4199 \\
(12.13)\end{array}$ \\
\hline PHD & $\begin{array}{r}0.5465 \\
(7.19)\end{array}$ & $\begin{array}{r}0.5035 \\
(15.87)\end{array}$ & $\begin{array}{r}0.5363 \\
(6.26)\end{array}$ & $\begin{array}{r}0.4944 \\
(11.78)\end{array}$ & $\begin{array}{r}0.6393 \\
(3.29)\end{array}$ & $\begin{array}{l}0.6171 \\
(10.91)\end{array}$ \\
\hline MANG & $\begin{array}{c}0.4671 \\
(13.86)\end{array}$ & $\begin{array}{l}0.3877 \\
(29.05)\end{array}$ & $\begin{array}{l}0.4611 \\
(11.95)\end{array}$ & $\begin{array}{l}0.4343 \\
(24.50)\end{array}$ & $\begin{array}{r}0.1852 \\
(2.52)\end{array}$ & $\begin{array}{l}0.2624 \\
(12.87)\end{array}$ \\
\hline PROF & $\begin{array}{c}0.4404 \\
(15.90)\end{array}$ & $\begin{array}{r}0.3490 \\
(31.17)\end{array}$ & $\begin{array}{r}0.3737 \\
(11.20)\end{array}$ & $\begin{array}{l}0.3060 \\
(18.92)\end{array}$ & $\begin{array}{r}0.4466 \\
(8.49)\end{array}$ & $\begin{array}{l}0.3576 \\
(23.07)\end{array}$ \\
\hline SKILLED & $\begin{array}{c}0.2374 \\
(10.35)\end{array}$ & $\begin{array}{r}0.1880 \\
(19.11)\end{array}$ & $\begin{array}{r}0.2255 \\
(8.13)\end{array}$ & $\begin{array}{l}0.2024 \\
(15.16)\end{array}$ & $\begin{array}{r}0.1659 \\
(4.05)\end{array}$ & $\begin{array}{r}0.1436 \\
(9.87)\end{array}$ \\
\hline LNWEEKS & $\begin{array}{r}0.7317 \\
(39.73) \\
\end{array}$ & $\begin{array}{r}0.8516 \\
(97.51) \\
\end{array}$ & $\begin{array}{r}0.7920 \\
(33.08) \\
\end{array}$ & $\begin{array}{r}0.8602 \\
(69.34) \\
\end{array}$ & $\begin{array}{l}0.6253 \\
(22.47)\end{array}$ & $\begin{array}{r}0.8412 \\
(69.38)\end{array}$ \\
\hline LAMBDA & $\begin{array}{r}0.9322^{*} \\
(1.78) \\
\end{array}$ & $\begin{array}{r}2.2111 \\
(5.18) \\
\end{array}$ & $\begin{array}{r}0.1236^{*} \\
(0.33) \\
\end{array}$ & $\begin{array}{r}0.6263 \\
(1.98) \\
\end{array}$ & $\begin{array}{r}0.5982 * \\
(1.45) \\
\end{array}$ & $\begin{array}{r}1.8850 \\
(5.45) \\
\end{array}$ \\
\hline Constant & $\begin{array}{c}6.8395 \\
(12.59)\end{array}$ & $\begin{array}{r}3.7363 \\
(14.08)\end{array}$ & $\begin{array}{r}6.0437 \\
(16.03)\end{array}$ & $\begin{array}{l}4.7262 \\
(17.73)\end{array}$ & $\begin{array}{l}6.7651 \\
(14.13)\end{array}$ & $\begin{array}{l}4.1127 \\
(18.75)\end{array}$ \\
\hline Adj. $\mathrm{R}^{2}$ & 0.34 & 0.37 & 0.35 & 0.39 & 0.28 & 0.35 \\
\hline Sample size & 6,951 & 33,661 & 4,650 & 17,295 & 2,301 & 16,366 \\
\hline
\end{tabular}

Although there are sizable differences in the coefficients across non-citizens and naturalized citizens by place of origin, most variables behave similarly and yield the expected signs as predicted by a human capital model. Only the official language dummy variable displays insignificant and near-zero values for its coefficient. This outcome can be explained by the fact that the majority of OECD immigrants in the selected population come from either English- or French-speaking countries. The impacts of various educational attainment variables and occupational choice as measured by their estimated coefficients are similar for naturalized citizens and non-citizens in both the OECD and non-OECD groups. The coefficient on weeks worked has a greater effect on naturalized citizens' earnings regardless of their source country.

The coefficient of the Inverse Mill's Ratio (IMR) or lambda represents the product of the standard deviation of the errors in the wage equation and the correlation 
between the wage equation error term and the selection equation error term. Lambda (IMR) is positive and significant for citizens, and positive and insignificant for noncitizens across OECD and non-OECD groups. The significance of the coefficients for the IMR in the citizens' equation indicates the importance of controlling for self-selection bias. This suggests that the results reported by DeVoretz and Pivnenko (2004b) were biased since they ignored self-selection.

Adjusted for self-selection bias, our results now suggest that the unobserved element in citizenship choice plays an important role in the earnings regressions. In fact, a positive lambda indicates a positive correlation between the error terms in the selection and wage equations. Thus, in our specification there are unobserved variables that both increase the probability of ascension to citizenship and lead to higher-than-average values for the dependent variable in earnings equation.

As noted above, since lambda is the correlation between the errors in the selection and wage equations, it is extremely sensitive to model specification, and therefore its interpretation will necessarily carry a certain degree of ambiguity. In Tables A-1 and A-3 (see Appendix A) the estimates for sub-samples of male and female immigrants display similar results, with one exception. The coefficient on lambda for female immigrants from OECD countries is significant and negative, whereas, for female immigrants from non-OECD countries, lambda was positive and highly insignificant regardless of the foreign-born citizenship status. A negative lambda suggests that unobserved factors tend to increase the likelihood of females acquiring citizenship, while they decrease female wages. This is consistent with the "crowding out" hypothesis. ${ }^{11}$ This hypothesis states that a group with a relatively high unemployment rate (in our case female immigrant workers) and a high-wage earnings potential displaces lower-wage earners by taking their lower-skilled jobs. In addition, those who remain at their jobs agree to lower pay in order to avoid displacement. Consequently, the observed wage distribution tends to underestimate the potential wage distribution in a situation of full employment (Nicaise, 2001).

\footnotetext{
${ }^{11}$ See Nicaise (2001) for a more complete exposition of the "crowding-out" hypothesis.
} 


\section{Selection equation}

In our earlier study we argued that the decision to ascend to citizenship is conditioned on the costs and benefits associated with citizenship status. We included age, the expected wage premium, as well as educational attainment, marital status and married with children dummies in the selection equation as factors that may affect the costs and benefits of citizenship.

Table 3 shows the maximum likelihood estimates of probit coefficients derived from the selection equation. In general, our model better predicts the citizenship decision for immigrants from non-OECD countries. For both source country groups the age variable has a positive effect on immigrant's decision to acquire Canadian citizenship, as older people demonstrate a stronger commitment to stay in Canada. Although marital status displays a significant and negative effect for the non-OECD group, a positive and significant coefficient for the interaction dummy in the same group indicates that the presence of children increases the likelihood of acquiring Canadian citizenship by married immigrants from poor countries.

Table 3: PROBIT estimation of regression coefficients in citizenship equation (t-ratios in brackets)

\begin{tabular}{|c|c|c|c|c|c|c|}
\hline & \multicolumn{2}{|c|}{ All Immigrants } & \multicolumn{2}{|c|}{ OECD Immigrants } & \multicolumn{2}{|c|}{ Non-OECD Immigrants } \\
\hline & $\begin{array}{l}\text { Estimated } \\
\text { Coefficient }\end{array}$ & $\begin{array}{l}\text { Marginal } \\
\text { Effect }\end{array}$ & $\begin{array}{c}\text { Estimated } \\
\text { Coefficient }\end{array}$ & $\begin{array}{l}\text { Marginal } \\
\text { Effect }\end{array}$ & $\begin{array}{l}\text { Estimated } \\
\text { Coefficient }\end{array}$ & $\begin{array}{l}\text { Marginal } \\
\text { Effect }\end{array}$ \\
\hline AGE & $\begin{array}{l}0.0274 \\
(19.00)\end{array}$ & 0.0018 & $\begin{array}{l}0.0183 \\
(14.83)\end{array}$ & 0.0045 & $\begin{array}{l}0.0322 \\
(12.80)\end{array}$ & 0.0007 \\
\hline DIPL & $\begin{array}{c}0.2133 \\
(7.31)\end{array}$ & 0.0144 & $\begin{array}{l}0.0569 \\
(2.37)\end{array}$ & 0.0141 & $\begin{array}{l}0.4403 \\
(8.43)\end{array}$ & 0.0089 \\
\hline $\mathrm{BACH}$ & $\begin{array}{c}0.3680 \\
(8.91)\end{array}$ & 0.0248 & $\begin{array}{l}0.0463 \\
(1.26)\end{array}$ & 0.0114 & $\begin{array}{l}0.5387 \\
(7.97)\end{array}$ & 0.0109 \\
\hline BACHPL & $\begin{array}{l}0.3277 \\
(6.33)\end{array}$ & 0.0221 & $\begin{array}{l}0.1092 \\
(2.45)\end{array}$ & 0.0269 & $\begin{array}{l}0.3056 \\
(3.58)\end{array}$ & 0.0062 \\
\hline PHD & $\begin{array}{c}0.2679 \\
(2.61)\end{array}$ & 0.0180 & $\begin{array}{l}-0.0205 \\
(-0.26)\end{array}$ & -0.0051 & $\begin{array}{l}0.7694 \\
(3.60)\end{array}$ & 0.0156 \\
\hline MAR & $\begin{array}{l}-0.1214 \\
(-3.33)\end{array}$ & -0.0082 & $\begin{array}{c}-0.0272 \\
(-0.91)\end{array}$ & -0.0067 & $\begin{array}{c}-0.2656 \\
(-4.13)\end{array}$ & -0.0054 \\
\hline MAR_CHL & $\begin{array}{l}0.0104 \\
(0.32)\end{array}$ & 0.0007 & $\begin{array}{c}-0.1001 \\
(-3.60)\end{array}$ & -0.0247 & $\begin{array}{l}0.1120 \\
(2.06)\end{array}$ & 0.0023 \\
\hline LWDIF & $\begin{array}{c}1.4368 \\
(104.39)\end{array}$ & 0.0968 & $\begin{array}{l}0.8585 \\
(63.88)\end{array}$ & 0.2119 & $\begin{array}{l}1.5020 \\
(60.14)\end{array}$ & 0.0305 \\
\hline CONSTANT & $\begin{array}{l}3.5006 \\
(50.05)\end{array}$ & & $\begin{array}{c}0.4520 \\
(7.92)\end{array}$ & & $\begin{array}{l}2.8780 \\
(25.80)\end{array}$ & \\
\hline $\begin{array}{l}\text { ESTRELLA } \\
\text { R-SQUARE }\end{array}$ & \multicolumn{2}{|c|}{0.6485} & \multicolumn{2}{|c|}{0.2225} & \multicolumn{2}{|c|}{0.6064} \\
\hline $\begin{array}{l}\text { NORMALIZED } \\
\text { SUCCESS INDEX }\end{array}$ & \multicolumn{2}{|c|}{0.704} & \multicolumn{2}{|c|}{0.231} & \multicolumn{2}{|c|}{0.712} \\
\hline
\end{tabular}

Source: Authors' calculations

In contrast, coefficients on the family characteristics mentioned above are both negative in the OECD group. Educational attainment positively affects the immigrant's 
citizenship decision and is a better predictor for non-OECD immigrants. Finally, as expected, the simulated citizen/non-citizen wage differential has a strong positive effect on the citizenship decision across both source country groups.

While results for sub-sample of non-OECD males (see Table A-2 in Appendix A) display a similar pattern as reported for the aggregate results in Table 3, the estimation for non-OECD males differ in some respects. First, the model shows a substantially improved goodness-of-fit. Second, educational qualifications have greater explanatory power on the citizenship decision. Finally, non-OECD male immigrants show a positive effect from the presence of children, with a strong negative coefficient on marital status.

\section{Decomposition Analysis}

The wage gap between the two immigrant groups may be owing to differences in individual characteristics and differences in returns to these characteristics. The OaxacaBlinder decomposition method (Oaxaca, 1973; Blinder, 1974) has become a routine method in labor market discrimination studies to explain segmented group wage differences. In our case the citizenship status of an immigrant segments the labour market, and thus we apply the decomposition theory. In its simplest version the idea is to isolate the fraction of wage differentials unexplained by human capital endowments usually ascribed as labor market discrimination. Accordingly, we have to adopt one of the estimated wage structures as the nondiscriminatory norm for the group believed to be dominant in the labor market (citizens) relative to the comparison group (non-citizens).

The human capital portion of the overall wage differential is obtained as a sum of the differences in the mean characteristics of the two groups weighted by the estimated coefficients for the nondiscriminatory wage standard. The portion of the overall wage differential owing to discrimination will then be the residual left over after netting out the human capital portion. ${ }^{12}$ In our study we adapt this decomposition methodology to explain citizen/non-citizen immigrant wage differentials. Further we treat non-citizens as a disadvantaged group since non-citizens are discriminated against in the public sector by blocking limited job access. Moreover, in the private sector citizenship status serves as a

12 This could also be directly calculated as a sum of the difference in estimated coefficients between the two groups weighted by the mean characteristics of the discriminated group. 
signal: first, it indicates an attachment to Canada, and, second, it may indicate greater cultural integration.

Neuman and Oaxaca (2003) acknowledged that a selectivity correction introduces some fundamental ambiguities in the context of wage decompositions, and therefore estimation of the wage gap in the presence of sample selection bias depends on the assumptions as well as objectives of the study. One of their suggested decomposition modifications we are using below. In our case, the selectivity component will be netted out of the endowment effect and, instead, combined with structural differences effect. These two effects will in turn be treated as a part of the wage differential unexplained by human capital characteristics.

Based on the estimates obtained earlier, we define the citizen/non-citizen wage differential in matrix notation as

$$
\ln W_{C}-\ln W_{N}=\left(\bar{X}_{C}-\bar{X}_{N}\right)^{T} \hat{\gamma}+\bar{X}_{N}^{T}(\hat{\beta}-\hat{\gamma})+\left(\hat{\gamma}_{3} \bar{\lambda}_{C}-\hat{\beta}_{3} \bar{\lambda}_{N}\right)
$$

where the first term on the right hand side represents the effect of the differences in mean characteristics, and the second term depicts the effect of differential returns to these characteristics, while the third term represents the selectivity residual. ${ }^{13}$

The decomposition results presented in Table 4 suggest that the observed wage differentials between citizens and non-citizens are largely attributed to the differences in immigrants' human capital endowments. Only a small portion accrues to other factors that include both the difference in returns and the effect of unobservable factors on the immigrant's ascension to citizenship.

\footnotetext{
${ }^{13}$ Vectors of the estimated coefficients from citizens and non-citizens wage equations ( $\hat{\beta}$ and $\hat{\gamma}$ ) exclude $\hat{\beta}_{3}$ and $\hat{\gamma}_{3}$ respectively.
} 
Table 4. Decomposition of wage differentials between naturalized citizens and permanent residents of Canada: population of foreign-born employees 25-65 years old

\begin{tabular}{|c|c|l|l|}
\hline & $\begin{array}{l}\text { Naturalized citizens } \\
\text { permanent residents } \\
\text { wage differential }\end{array}$ & $\begin{array}{l}\text { Difference } \\
\text { unexplained by human } \\
\text { capital endowments } \\
\text { (structural differences } \\
\text { and selectivity) }\end{array}$ & $\begin{array}{l}\text { Differences due to the } \\
\text { human capital } \\
\text { endowments }\end{array}$ \\
\hline All & $\mathbf{1 7 \%}$ & $2 \%$ & $15 \%$ \\
\hline Males & $\mathbf{1 4 . 9 \%}$ & $-6.2 \%$ & $21.1 \%$ \\
\hline Females & $\mathbf{1 6 . 3 8 \%}$ & $13.6 \%$ & $2.8 \%$ \\
\hline OECD & $\mathbf{1 3 . 4 \%}$ & $4 \%$ & $9.4 \%$ \\
\hline Males & $\mathbf{1 1 . 2 \%}$ & $-1.6 \%$ & $12.8 \%$ \\
\hline Females & $\mathbf{1 0 . 5} \%$ & $13.8 \%$ & $-3.5 \%$ \\
\hline NON-OECD & $\mathbf{3 3 \%}$ & $8.3 \%$ & $24.7 \%$ \\
\hline Males & $\mathbf{3 2 . 7} \%$ & $8.5 \%$ & $24.2 \%$ \\
\hline Females & $\mathbf{3 2 . 9} \%$ & $9.1 \%$ & $23.8 \%$ \\
\hline Sour Aun & & \\
\hline
\end{tabular}

Source: Authors' calculations

For our general sample of employed immigrants, we detected a wage differential of $17 \%$ between citizens and non-citizens. However, the structure of the wage differentials varies across gender, as shown in Table 4 . Over $80 \%$ of the female citizens' advantage over non-citizens is attributed to the difference in returns to their labour market characteristics and selectivity, whereas male citizens demonstrate higher wages due to a better endowment despite the unfavorable combined effect of other factors.

In general, immigrant citizens from non-OECD countries enjoyed a larger wage advantage than non-citizens from OECD countries (33\% vs. 13.4\%).

For both males and females from non-OECD countries, about two thirds of the observed wage differentials are attributed to better human capital endowments of citizens. However, for immigrant citizens from OECD countries the structure of earnings advantage differs by gender. In this group the human capital component explains the entire wage gap for males, while the favorable difference in returns and selectivity offsets some of the negative effect derived from the endowment component for females.

If we compare these results to the decomposition estimates made in the presence of selectivity bias (Table 5-A in Appendix A) then we observe that our correction procedure increases the proportion of the endowment effect across both gender groups, 
with the exception of females from OECD countries. ${ }^{14}$ This upward adjustment suggests that, after controlling for the combined impact of unobserved selectivity factors, the human capital component in the observed wage gap between citizens and non-citizens becomes more important.

\section{Public Finance Implications of Citizenship}

Theory

A crucial and reoccurring question in the minds of immigration critics is: "Do the foreign born make a net positive contribution to the treasury?" We expand this question here by asking if the naturalized foreign-born contribute more or less than non-citizens to the treasury. If citizen status increases income opportunities, then, under a progressive tax system, naturalized citizens should contribute more to the treasury. It is however possible that ascension to citizenship increases public entitlements. Hence, the impact of citizenship on public finance transfers is ambiguous.

Simon (1984) provides us with a theoretical framework to answer the question formulated above by suggesting that income and, therefore, tax payments, are concave in age, while public transfers consumption is convex in age, as shown in figure 2 .

\footnotetext{
${ }^{14}$ We investigate the composition of the observed wage differential between citizens and non-citizens before and after controlling for selectivity, hence the percentage of the reported wage gap remains unchanged in both experiments.
} 


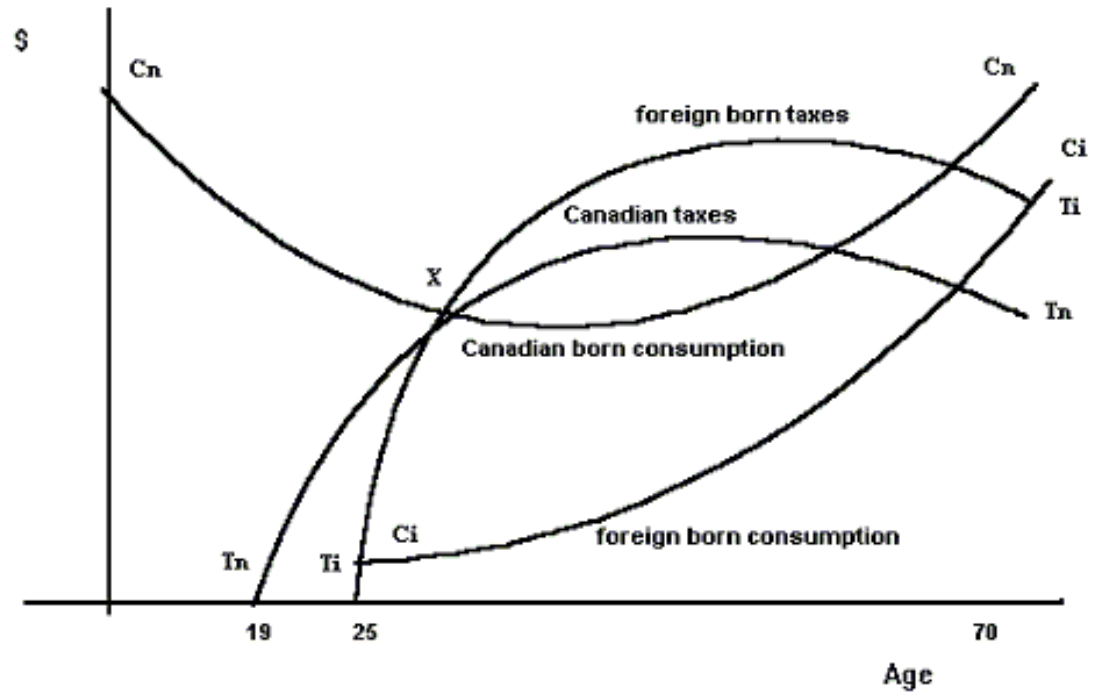

In addition, DeVoretz and Pivnenko (2004b) suggest that many Canadian naturalized citizens may be selected three times: first, by themselves when they choose to immigrate; secondly, by Canada via the point system; and by the naturalization process. Thus, the hypothesized age transfer patterns may vary by birth and citizenship status. The effect of this triple selection is observed in many dimensions. First, Canadian-born residents start consuming public finance transfers (denoted $\mathrm{Cn}-\mathrm{Cn}$ in Figure 2) for health services at birth, and then, at the age of six, receive educational subsidies. Next, between ages 19 and 22, the Canadian-born population simultaneously exits the education sector and enters the labour force. This reduces their consumption of subsidized education and associated government transfers. At this point in the life cycle, the Canadian-born begin to pay taxes (Tn-Tn). In contrast to this life-cycle pattern, the foreign-born's public good consumption curve (Ci-Ci) begins later, after entry to Canada (i.e. age 26) and may lie everywhere below (or above) the public good consumption curve for its Canadian-born cohort, depending upon economic and demographic circumstances.

The ambiguity in the level of consumption of public transfers by the foreign-born, naturalized or not, at every age, results from two countervailing forces. On the one hand, 
the immigrant's initial lack of eligibility to consume some subsidized services, such as health, is tied to residency requirements. Other programs, such as (Un)Employment Insurance, are income-contingent and, thus, may reduce immigrant access to public transfers. On the other hand, the initial risk faced by the immigrants in the labour market could lead to their greater use of entitlement programs, such as social assistance, upon arrival. Finally, it is hypothesized that initially low foreign-born tax payments (Ti-Ti) accelerate to a "“crossover" point (at X), where tax payments by the foreign-born exceed those of the Canadian-born as a result of higher foreign-born earnings because of citizenship acquisition and of the progressive nature of Canada's tax system.

Figure 2 best represents the optimistic case. A pessimistic case (Figure 3) would have the foreign-born earn less and never "catch-up" to the Canadian-born where earnings are concerned, and this would result in lower tax payments. It would also delay or completely forestall their tax "crossover." In this case, given a low household income, the foreignborn consumption of government transfers would lie above that predicted in Figure 2.

Figure 3: Age-Consumption Tax Profiles by Birth Status: Pessimistic Case

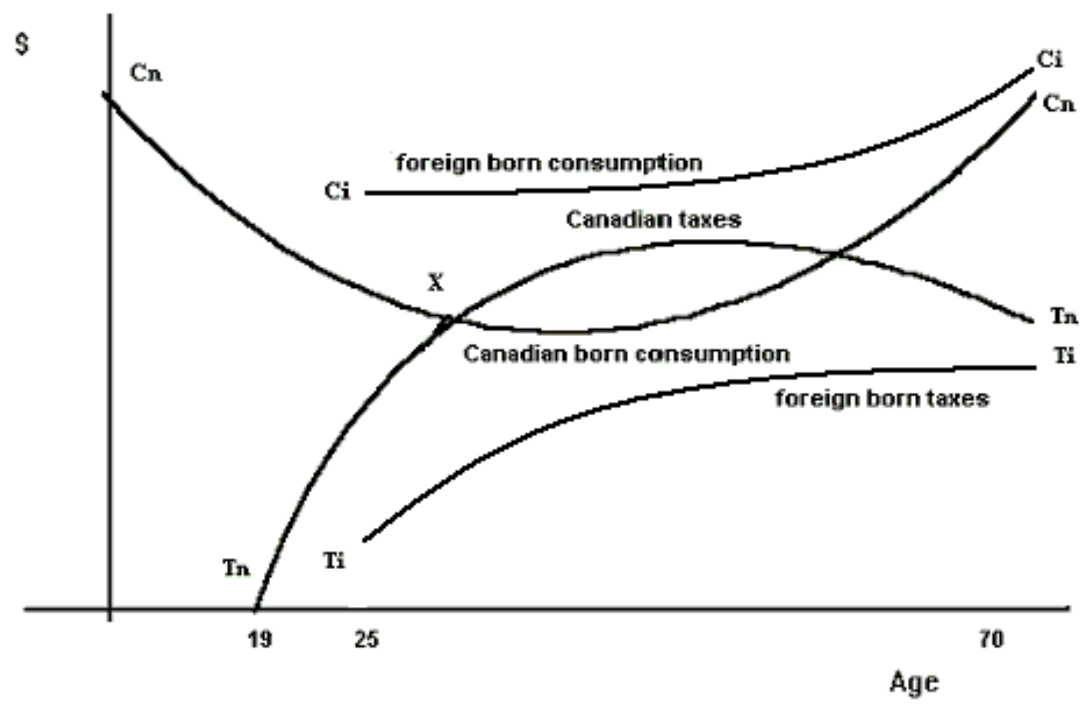


This life-cycle transfer model described in figures 2 and 3 was estimated in Canadian context by DeVoretz and Pivnenko (2004a), and represents a flexible theoretical tool.

Total federal government net treasury payments in 1995 by birthplace and citizenship status of the head of household are reported in figure 4. These government transfers to the federal treasury are a result of calculating taxes paid minus the receipt of pensions, child tax credits, employment benefits and other money transfers by individual households. ${ }^{15}$

Figure 4: Net Treasury Payments by Canadian-born and Foreign-born by citizenship status, 1995

(5-year moving average)

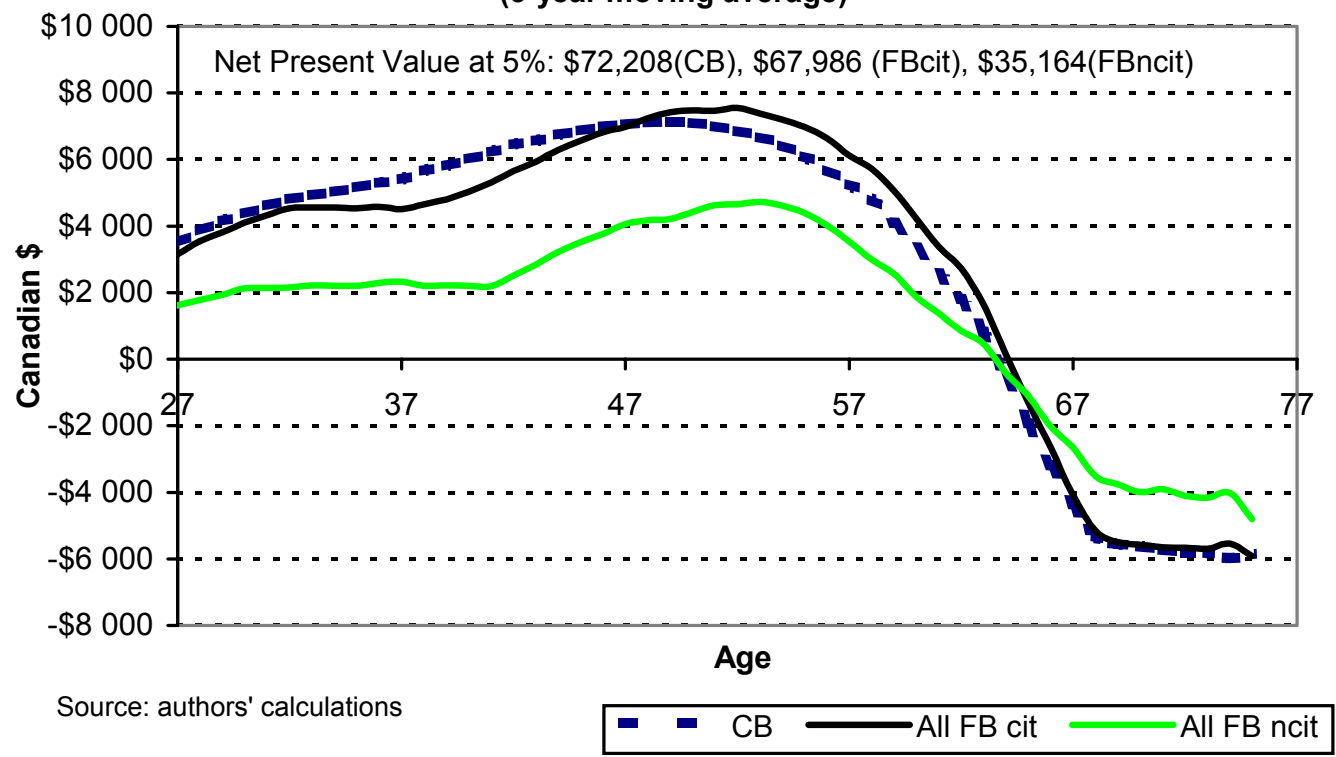

Foreign birth status and citizenship status have two separate effects on life-cycle transfer payments. Being a non-citizen in Canada substantially reduces net treasury payments. However treasury transfer contributions rise when the immigrant ascends to citizenship, and exceed the native-born transfers after age 50. In fact, a naturalized citizen transfers a discounted value of $\$ 67,986$ to the federal treasury, an amount almost equal to

\footnotetext{
${ }^{15}$ Federal taxes consist of the income tax and GST paid per household. Calculation of a household income tax rate was based on the reported household income and the applicable average and marginal tax rates after appropriate household deductions were made. The GST contribution was derived by taking the average propensity to consume, as reported in FAMEX 1995, for a similar household, multiplied by the appropriate GST or HST in the relevant province. See Appendix C for details.
} 
the Canadian-born contribution of $\$ 72,208$, but greatly superior to the non-citizen lifetime discounted transfer of $\$ 35,164$. $^{16}$

We can expand this analysis to complement our earlier work by estimating net treasury transfers for OECD and non-OECD immigrants by citizenship status as reported in figures 5 and $6 .{ }^{17}$

Figure 5: Net Treasury Transfers for Canadian-born and OECD immigrants by citizenship status, 1995 (5-year moving average)

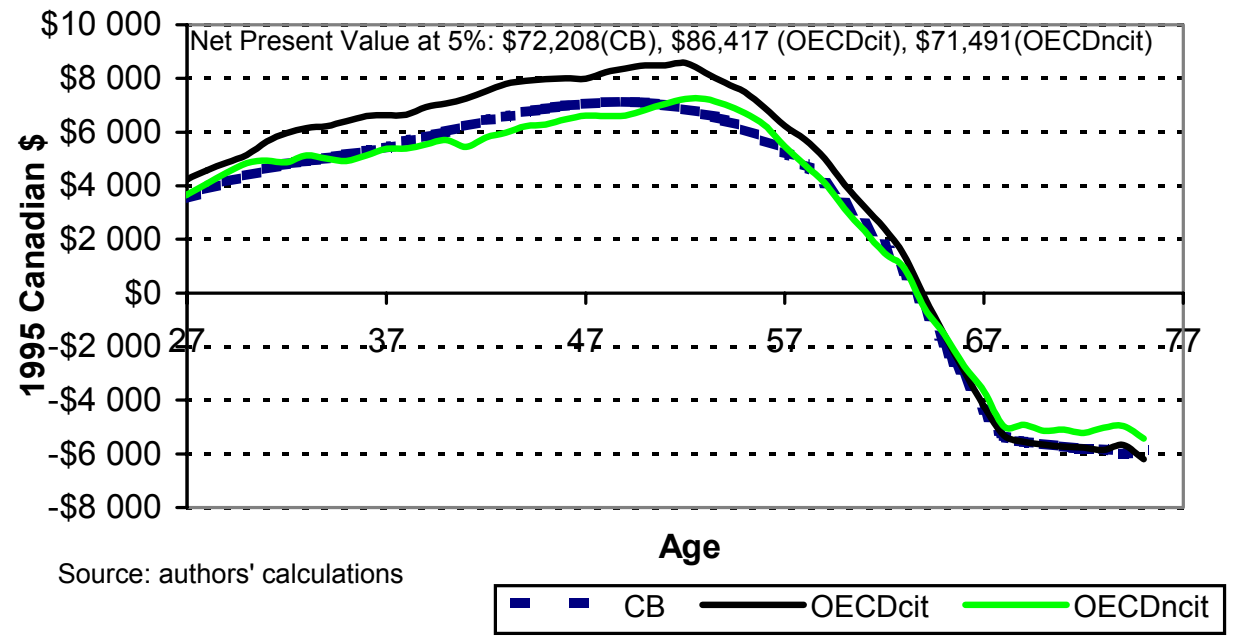

Figure 5 reveals that naturalized citizens from the OECD transfer more to the treasury over their entire lifetime than either Canadian-born citizens or non-citizens from the OECD. Figure 6 however portrays the dramatic effect of citizenship status on the size of public transfers for immigrants from non-OECD countries: Canadian citizens generally transfer twice as much as non-citizens from non-OECD countries each year in the lifecycle.

${ }^{16}$ The net present value $=N P V=\sum_{i=27}^{i=75} \frac{\left(\text { TotTax }_{i}-\text { GovTrans }_{i}\right)}{(1+r)^{t}}$ where $\mathrm{r}=.05, \mathrm{t}=1$ when $\mathrm{i}=27$ all in 1995 dollars.

${ }^{17}$ OECD countries include: France, Germany, Greece, Italy, the Netherlands, Portugal, Spain, the United Kingdom, and the United States. Non-OECD countries include: China (PRC), India, Lebanon, the Philippines, Poland, former USSR (European), Vietnam, and former Yugoslavia. 
Figure 6: Net Treasury Transfers Profiles for Canadian-born and NonOECD immigrants by citizenship status, 1995

(5-year moving average)

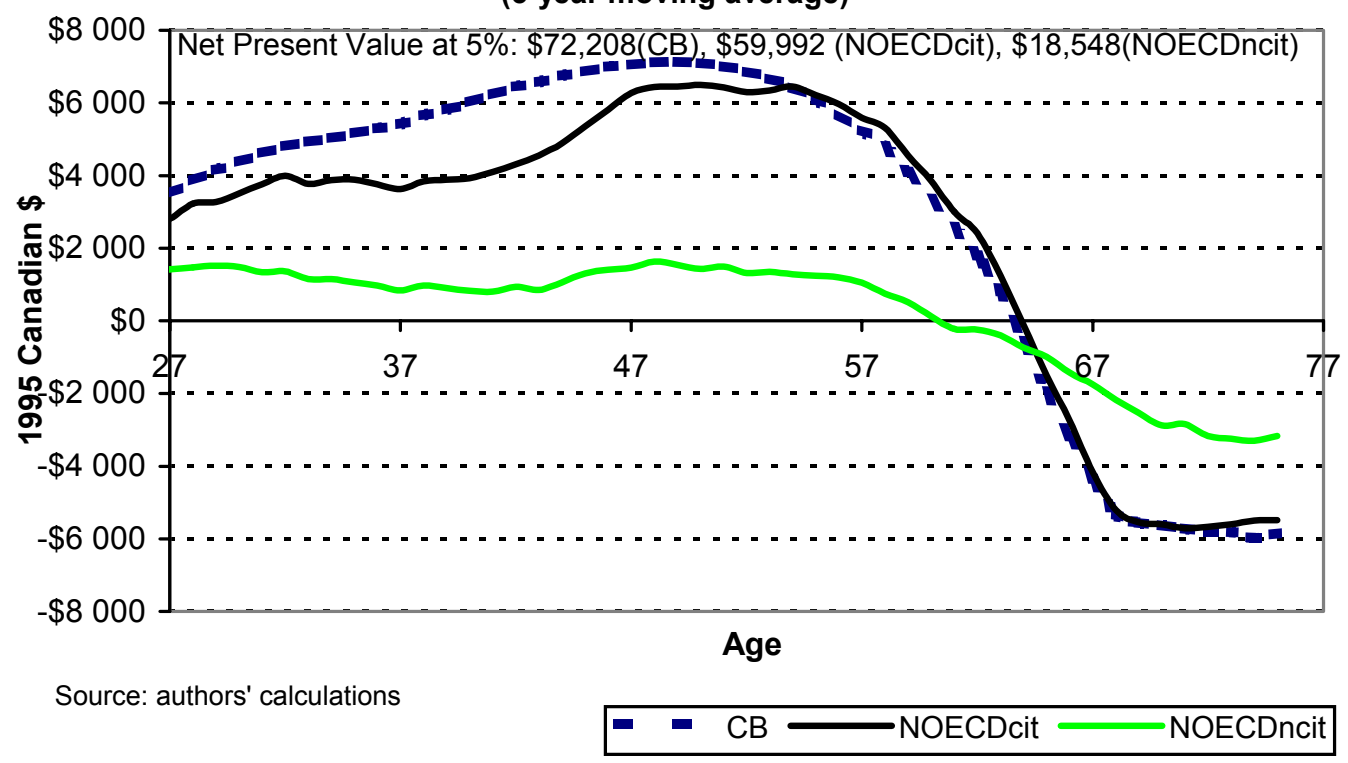

These treasury transfers are summarizec across citizenship and place of birth status in Table 5. By place of birth, OECD citizens transfer the largest amount, followed by the Canadian-born and all naturalized citizens. Moreover, citizenship status for all foreign-born groups has a larger impact on public finance contributions than birth status, except for immigrants from the OECD.

Table 5: Net Present Value of Public Finance Transfers: 1995 dollars, 5\% rate

\begin{tabular}{|l|c|c|c|c|}
\hline & $\begin{array}{c}\text { Canadian- } \\
\text { born }\end{array}$ & $\begin{array}{c}\text { All } \\
\text { Foreign-born }\end{array}$ & $\begin{array}{c}\text { OECD } \\
\text { immigrants }\end{array}$ & $\begin{array}{c}\text { Non-OECD } \\
\text { immigrants }\end{array}$ \\
\hline Citizens & $\mathbf{\$ 7 2 , 2 0 8}$ & $\mathbf{\$ 6 7 , 9 8 6}$ & $\mathbf{\$ 8 6 , 4 1 7}$ & $\mathbf{\$ 5 9 , 9 9 2}$ \\
\hline Non-Citizens & & $\mathbf{\$ 3 5 , 1 6 4}$ & $\mathbf{\$ 7 1 , 4 9 1}$ & $\mathbf{\$ 1 8 , 5 4 8}$ \\
\hline
\end{tabular}

Are these differential treasury transfers by citizenship status a result of tax payments, use of federal services, or both? Figure 7 illustrates the large impact on tax payments owing to citizenship for non-OECD immigrants, and a much more moderate citizenship impact for the OECD immigrant group. 
Figure 7: Net Treasury Transfers Profilesfor immigrants from OECD and non-OECD countries by citizenship status

(5-year moving average)

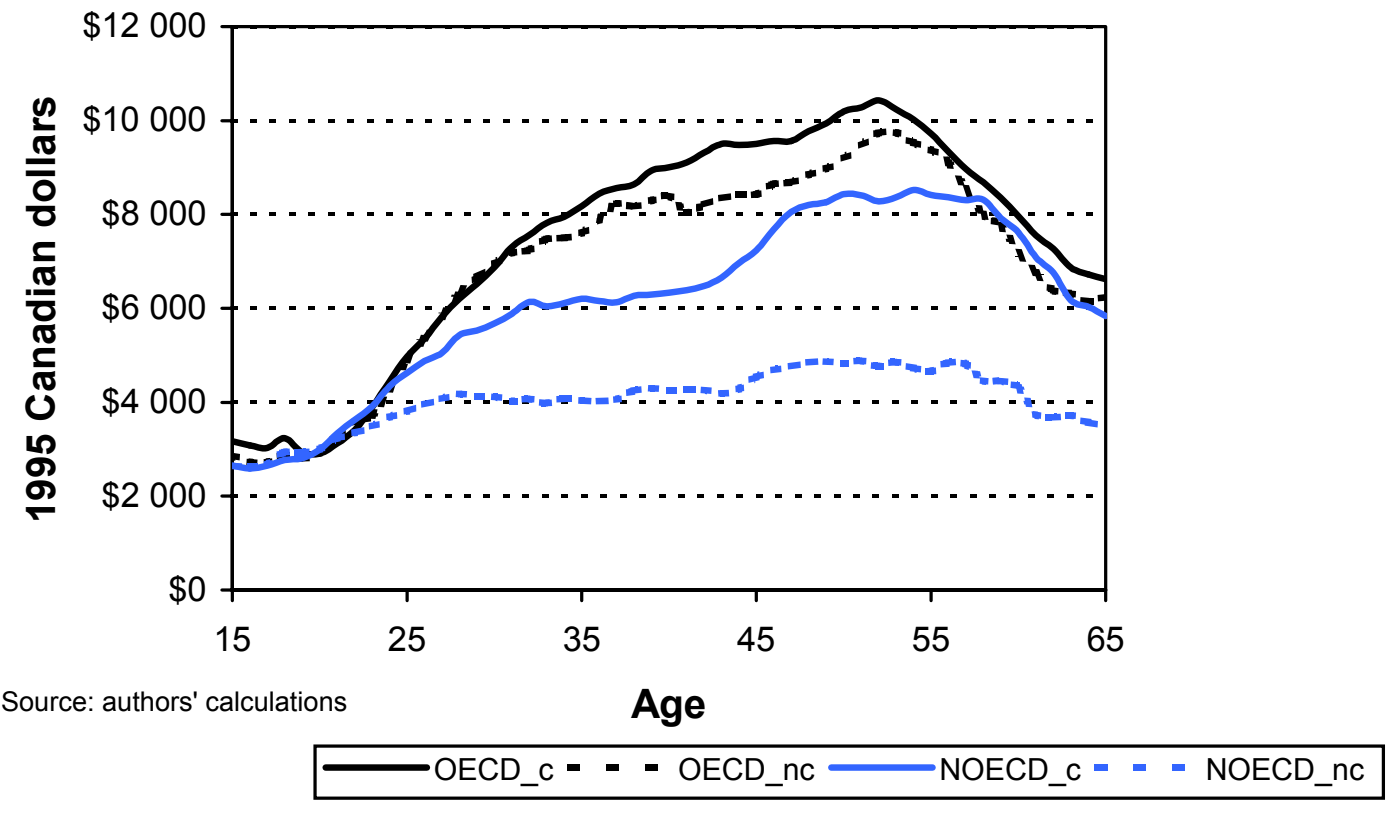

Figure 8 portrays the impact of citizenship and birth status on the consumption of federally financed services. There is no citizenship effect by place of birth except after retirement (65) when the lack of consumption of pensions by non-citizens from nonOECD countries (NOECDncit) restrains their use of public service.

Figure 8: Net Treasury Transfers Profiles for immigrants from OECD and non-OECD countries by Canadian citizenship status

(5-year moving average)

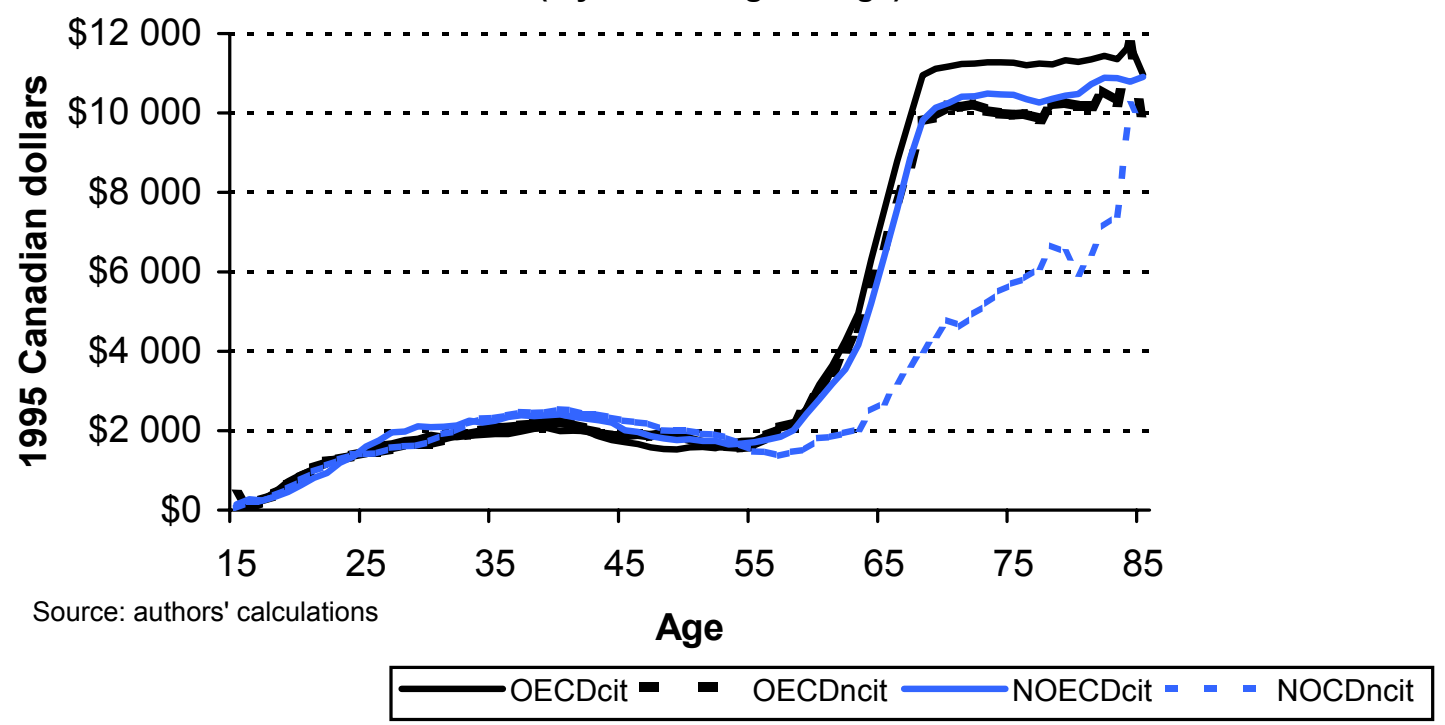


Figure 9 documents this effect in more detail. After age 65 federal pension payments grow for all naturalized citizens and non-citizen OECD immigrants but not for non-OECD immigrants who have not ascended to citizenship. This corresponds to the findings of Shamsuddin and DeVoretz (1999) who noted that the newest wave of immigrants are less eligible for government-financed pensions.

Figure 9: Pension Payments Profiles for immigrants from OECD and nonOECD countries by Canadian citizenship status

(3-year moving average)

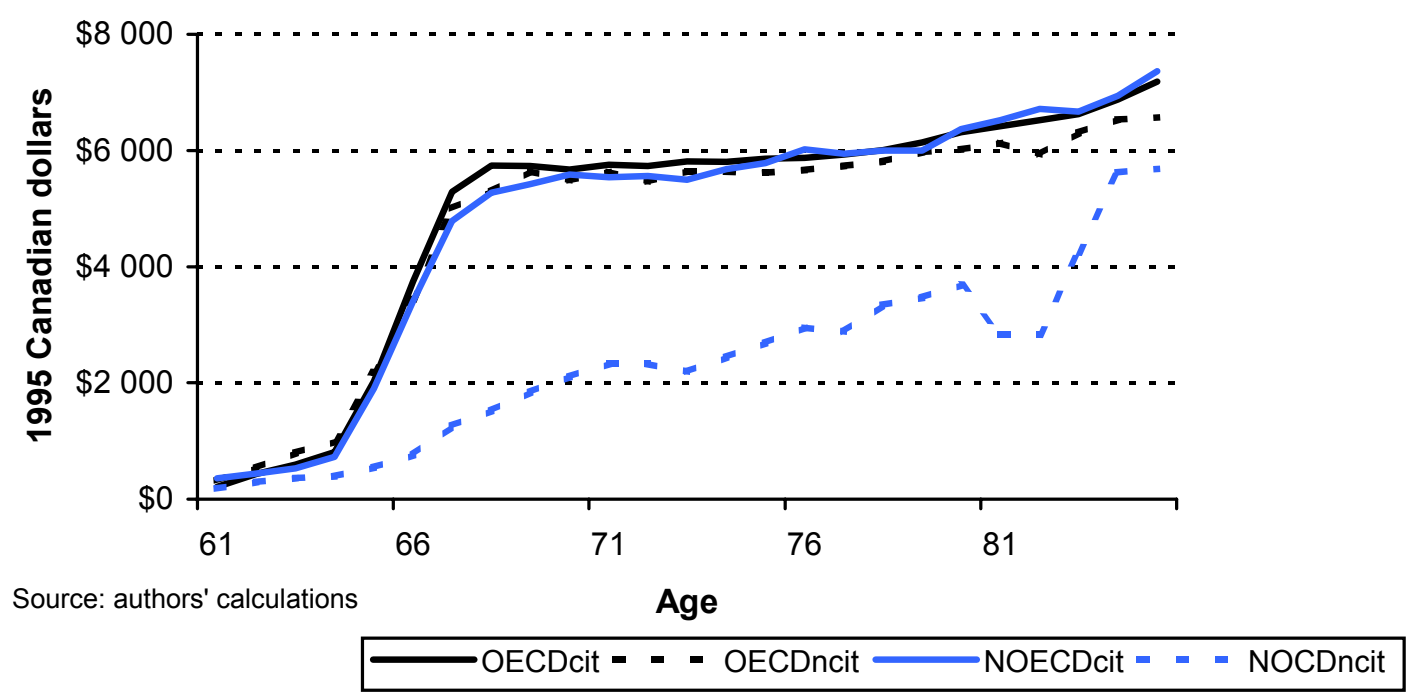

\section{Conclusions}

At the micro level, our analysis of the economic implications of Canadian citizenship focused on the individual determinants of the naturalization decision and on the subsequent earnings performance of immigrants. Despite specification difficulties and demanding data requirements, our model based on Heckman's selectivity correction procedure generated some important conclusions.

First, possible selectivity bias has to be taken into account in the analysis of immigrants' earnings performance across their citizenship status. Our results showed that the significance and the magnitude of the selectivity effects varied by gender and source country groups. Furthermore, the Oaxaca decomposition results derived from the selectivity corrected earnings equations demonstrated the importance of the endowments component as compared to the estimates made in the presence of selection bias. 
Second, we confirmed our earlier findings that the naturalization decision is conditioned by the expected wage gain, level of education, marital status, age and presence of children. Statistically stronger results were obtained with the non-OECD immigrant group.

At the macro level, our study focused on the implications of Canadian citizenship for the lifetime public finance contributions of immigrants. We found evidence that all immigrants, regardless of their source country group and citizenship status, make positive contributions to Canada's treasury over their life cycle. Naturalized citizens from OECD countries demonstrated the highest net present value of public finance transfers exceeding the corresponding value for the Canadian-born by more than $\$ 14,000$. As expected, our estimates indicate that naturalized citizens made higher net contributions than their noncitizen counterparts regardless of source country. This difference was smaller among the immigrants from OECD countries $(\$ 86,417$ vs. $\$ 71,491)$, and substantially bigger in the non-OECD immigrant group ( $\$ 59,992$ vs. $\$ 18,548)$. The relatively poor public finance performance of non-citizens in the latter group was primarily explained by their low income and their low level of tax payments over the entire lifespan. In contrast to the other three groups that displayed almost identical pension and transfer acquisition profiles, the non-citizens from non-OECD countries received considerably smaller government transfers and lower pensions after the age of 55 .

In a broader study DeVoretz and Pivnenko (2004a) found similar outcomes with a different data set and sample coverage. In fact, for all-Canada sample, the reported ratios of net treasury transfers by foreign born relative to Canadian born are almost identical. ${ }^{18}$

In sum, citizenship status has micro and macro economic implications in Canada.

\footnotetext{
${ }^{18}$ Simple calculation based on the weighted average of the foreign-born citizen and non-citizen transfers from Table 5 yields the foreign born/Canadian born transfers ratio equal to .86 , whereas DeVoretz and Pivnenko (2004a, p.167, Table 3) report 0.84.
} 


\section{References}

Barkan E.R. and N. Khokhlov. 1980. Socioeconomic data as indices of naturalization patterns in the United States: A theory revisited. Ethnicity, 7: 159-190.

Bengston, T. and K. Scott. Forthcoming. Immigrant Consumption of Sickness Benefits in Sweden 1981-1991. Journal of Socio-Economics.

Bernard, W.S. 1936. Cultural Determinants of Naturalization. American Sociological Review, 1: 943-953.

Bevelander, P. 2000. Immigrant Employment Integration and Structural Change in Sweden: 1970-1995. Lund Studies in Economic History 15. Lund: Lund University Press.

Blinder, Alan. 1974. Wage Discrimination: Reduced Form and Structural Estimates, The Journal of Human Resources 8:436-455.

Bratsberg B., J. F. Ragan and Z.M. Nasir. 2002. The effect of naturalization on wage growth: A panel study of young male immigrants. Journal of Labor Economics, 20(3): 568-597.

Cotton, J. 1988. On the Decomposition of Wage Differentials. Review of Economics and Statistics 70 (2): 236-243.

DeVoretz, D.J. and S. Pivnenko. 2004a. Immigrant Public Policy Transfers: A Comparative Analysis by City. Canadian Journal of Urban Research, 13( ): 155-169.

. 2004b. The Economic Causes and Consequences of Citizenship. RIIM Working Paper No. 04-21; IZA Working Paper No. 1395.

DeVoretz, D.J. and K. Zhang. 2004 . Citizenship, Passports and the Brain Exchange Triangle. Journal of Comparative Policy Analysis Vol. 4, No. 1.

Heckman, J. 1976. The Common Structure of Statistical Models of Truncation, Sample Selection and Limited Dependent Variables and a Simple Estimator for Such Models. Annals of Economic and Social Measurement, pp. 475-92.

Kelley, J., and I. McAllister. 1982. The decision to become an Australian citizen. Australian and New Zealand Journal of Sociology, 18(3): 428-439.

Lee, L. F. 1978. Unionism and Wage Rates: A Simultaneous Equations Model with Qualitative and Limited Dependant Variables. International Economic Review, Vol. 19, 415-433. 
Mata, F. 1999. Patterns of Acquiring Citizenship. In S.S. Halli and L. Driedger (eds.), Immigrant Canada: Demographic, Economic and Social Challenges. Toronto: University of Toronto Press, 163-182.

Neuman, S. and R. Oaxaca. 2003. Estimating Labor Market Discrimination with Selectivity Corrected Wage Equations: Methodological Considerations and an illustration from Israel. The Pinhas Sapir Center for Development Paper No. 2-2003.

Nicaise, I. 2001. Human capital, reservation wages and job competition: Heckman's lambda re-interpreted. Applied Economics, 33(3): 309-315.

Oaxaca, R. 1973. Male-Female Wage Differentials in Urban Labor Markets.International Economic Review, Vol. 14, pp. 693-709.

Pivnenko, S. and D. J. DeVoretz. 2004. The Recent Economic Performance of Ukrainian Immigrants in Canada and the US. RIIM Working Paper No. 03-10; IZA Working Paper No. 913.

Portes, A., and Curtis, J.W. 1987. Changing flags: Naturalization and its determinants among Mexican Immigrants. International Migration Review, 21(2): 352-371.

Portes, A., and R. Mozo 1985. The political adaptation process of Cubans and other ethnic minorities in the United States: A preliminary analysis. International Migration Review, 16(1): 35-63.

Robinson, C. and N. Tomes. 1982. Self-Selection and Inter provincial Migration in Canada. Canadian Journal of Economics, 25(3): 474-502.

Scott, K. 2004. The Economics of Citizenship. Is there a Naturalization Premium? Paper presented at the conference Immigrant Ascension to Citizenship: Economic and Social Consequences. June 7, IMER, Malmö University.

Shamsuddin, A.F.M. and D.J. DeVoretz. 1999. Wealth accumulation of Canadian and foreign-born households in Canada. Review of Income and Wealth, Dec. 515-553.

Simon, J. 1984. Immigrants, taxes, and welfare in the United States. Population and Development Review 10(1): 55-69.

Yang, P.Q. 1994. Explaining Immigrant Naturalization. International Migration Review, 28(3): 449-477. 
Appendix A: Male and Female Wage and Citizenship Models

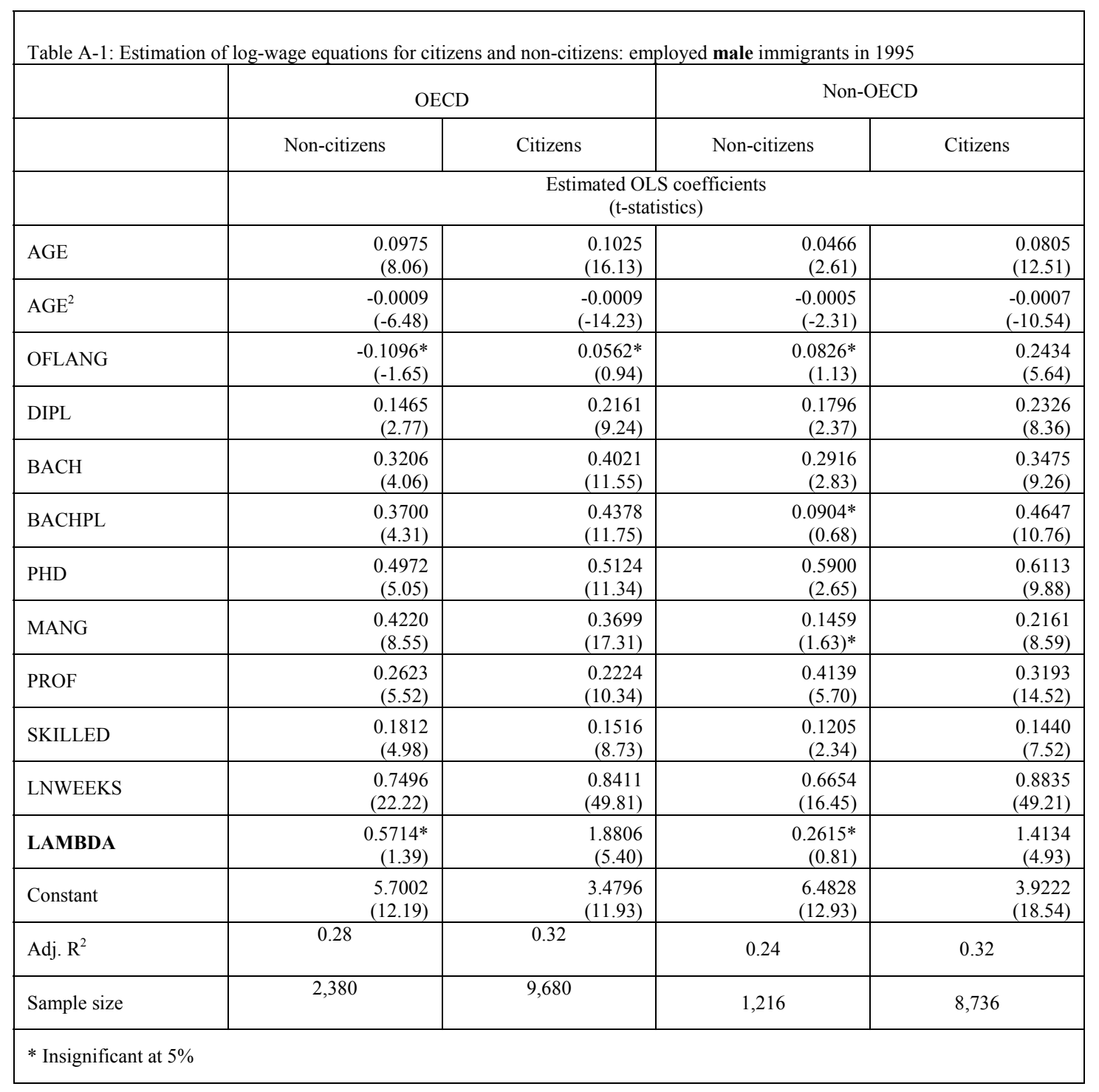


Table A-2: PROBIT estimation of citizenship equation: male immigrants

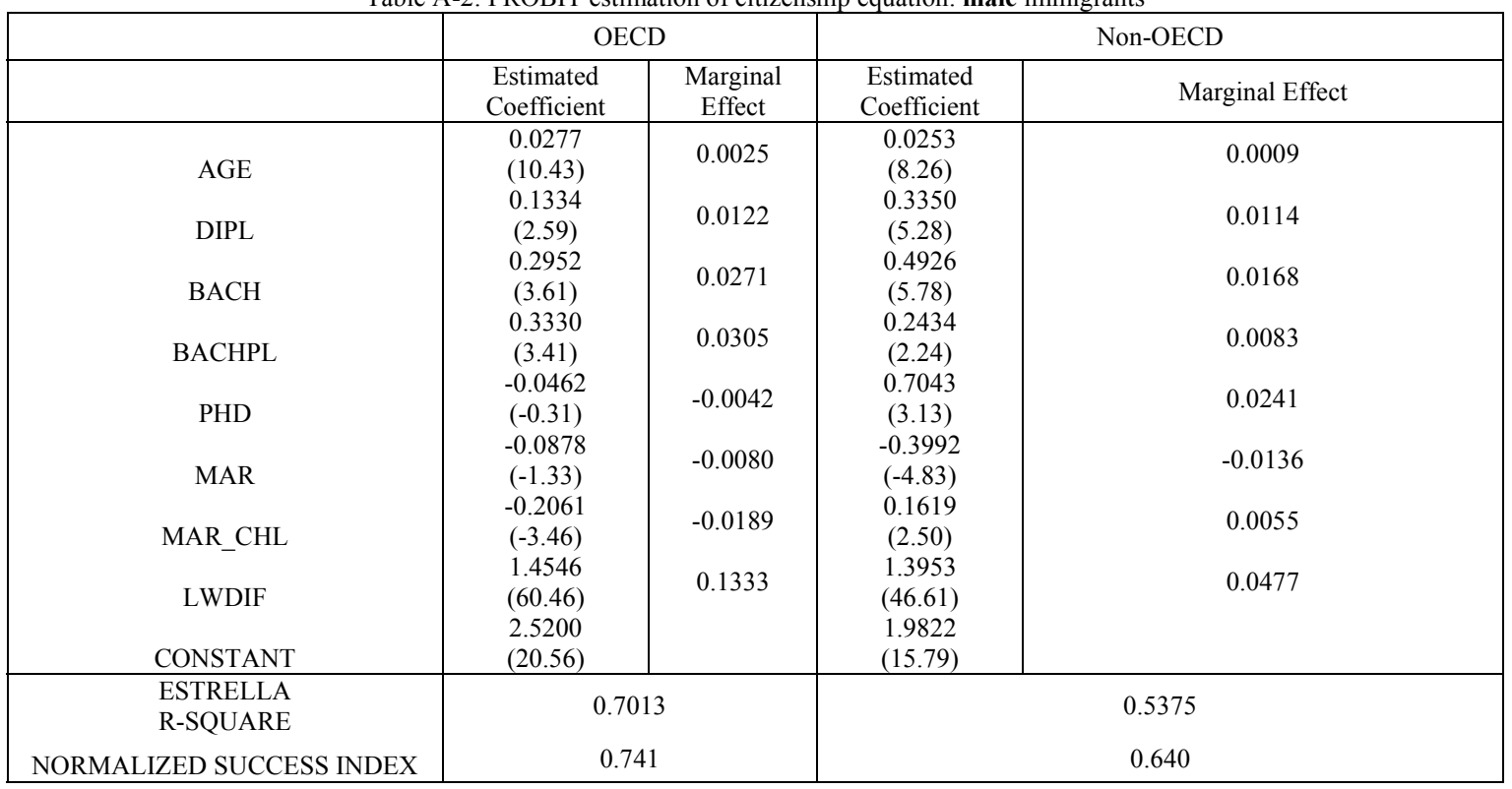

\begin{tabular}{|c|c|c|c|c|}
\hline & \multicolumn{2}{|c|}{ OECD } & \multicolumn{2}{|c|}{ Non-OECD } \\
\hline & Non-citizens & Citizens & Non-citizens & Citizens \\
\hline & \multicolumn{4}{|c|}{$\begin{array}{c}\text { Estimated OLS coefficients } \\
\text { (t-statistics) }\end{array}$} \\
\hline AGE & $\begin{array}{r}-0.0092 \\
(-0.66) \\
\end{array}$ & $\begin{array}{r}0.0187 \\
(2.12) \\
\end{array}$ & $\begin{array}{r}0.0555 \\
(4.08) \\
\end{array}$ & $\begin{array}{r}0.0662 \\
(7.53) \\
\end{array}$ \\
\hline $\mathrm{AGE}^{2}$ & $\begin{array}{r}-0.0001 \\
(-0.85) \\
\end{array}$ & $\begin{array}{r}-0.0005 \\
(-6.83) \\
\end{array}$ & $\begin{array}{r}-0.0004 \\
(-3.05) \\
\end{array}$ & $\begin{array}{r}-0.0005 \\
(-7.78) \\
\end{array}$ \\
\hline OFLANG & $\begin{array}{r}0.0025 \\
(0.03)\end{array}$ & $\begin{array}{r}0.0814 \\
(1.09)\end{array}$ & $\begin{array}{r}0.1804 \\
(4.03)\end{array}$ & $\begin{array}{r}0.1474 \\
(4.45)\end{array}$ \\
\hline DIPL & $\begin{array}{r}-0.0403 \\
(-1.02) \\
\end{array}$ & $\begin{array}{r}0.0145 \\
(0.70) \\
\end{array}$ & $\begin{array}{r}0.2166 \\
(3.25)\end{array}$ & $\begin{array}{r}0.2105 \\
(6.78) \\
\end{array}$ \\
\hline $\mathrm{BACH}$ & $\begin{array}{r}0.2537 \\
(4.11)\end{array}$ & $\begin{array}{r}0.3599 \\
(10.28)\end{array}$ & $\begin{array}{r}0.2546 \\
(3.22)\end{array}$ & $\begin{array}{r}0.3514 \\
(9.42)\end{array}$ \\
\hline BACHPL & $\begin{array}{r}0.3410 \\
(4.78)\end{array}$ & $\begin{array}{r}0.4034 \\
(10.38)\end{array}$ & $\begin{array}{r}0.1313 \\
(2.25)\end{array}$ & $\begin{array}{r}0.2895 \\
(10.01)\end{array}$ \\
\hline PHD & $\begin{array}{r}1.2255 \\
(5.27) \\
\end{array}$ & $\begin{array}{r}1.1864 \\
(8.33) \\
\end{array}$ & $\begin{array}{r}0.4748 \\
(3.25) \\
\end{array}$ & $\begin{array}{r}0.4398 \\
(5.65) \\
\end{array}$ \\
\hline MANG & $\begin{array}{r}0.5027 \\
(8.13)\end{array}$ & $\begin{array}{l}0.4966 \\
(14.90)\end{array}$ & $\begin{array}{r}0.3207 \\
(5.09)\end{array}$ & $\begin{array}{r}0.3755 \\
(14.79)\end{array}$ \\
\hline PROF & $\begin{array}{r}0.4455 \\
(9.67) \\
\end{array}$ & $\begin{array}{r}0.3840 \\
(15.19)\end{array}$ & $\begin{array}{l}0.4415 \\
(11.21)\end{array}$ & $\begin{array}{l}0.4088 \\
(24.63)\end{array}$ \\
\hline SKILLED & $\begin{array}{r}0.2558 \\
(5.95) \\
\end{array}$ & $\begin{array}{r}0.2357 \\
(10.89) \\
\end{array}$ & $\begin{array}{r}0.1793 \\
(4.81) \\
\end{array}$ & $\begin{array}{r}0.1721 \\
(10.32) \\
\end{array}$ \\
\hline LNWEEKS & $\begin{array}{l}0.8405 \\
(24.96)\end{array}$ & $\begin{array}{c}0.8698 \\
(46.28)\end{array}$ & $\begin{array}{c}0.6968 \\
(34.66)\end{array}$ & $\begin{array}{l}0.8250 \\
(65.61)\end{array}$ \\
\hline LAMBDA & $\begin{array}{r}-1.7360 \\
(-2.95)\end{array}$ & $\begin{array}{r}-3.6099 \\
(-7.10)\end{array}$ & $\begin{array}{r}0.8632 \\
(2.09)\end{array}$ & $\begin{array}{r}1.2409 \\
(3.49)\end{array}$ \\
\hline Constant & $\begin{array}{r}.8694 \\
(8.80)\end{array}$ & $\begin{array}{l}8.1139 \\
(17.51)\end{array}$ & $\begin{array}{l}6.1619 \\
(21.84)\end{array}$ & $\begin{array}{l}4.1034 \\
(10.57)\end{array}$ \\
\hline Adj. $\mathrm{R}^{2}$ & 0.31 & 0.33 & 0.31 & 0.33 \\
\hline Sample size & 2,289 & 7,071 & 3,614 & 13,686 \\
\hline
\end{tabular}


Table A-4: PROBIT estimation of citizenship equation: female immigrants

\begin{tabular}{|c|c|c|c|c|}
\hline & \multicolumn{2}{|c|}{ OECD } & \multicolumn{2}{|c|}{ Non-OECD } \\
\hline & $\begin{array}{c}\text { Estimated } \\
\text { Coefficient }\end{array}$ & $\begin{array}{l}\text { Marginal } \\
\text { Effect }\end{array}$ & $\begin{array}{l}\text { Estimated } \\
\text { Coefficient }\end{array}$ & Marginal Effect \\
\hline AGE & $\begin{array}{c}0.0542 \\
(6.89)\end{array}$ & 0.0011 & $\begin{array}{l}0.0338 \\
(24.89)\end{array}$ & 0.0086 \\
\hline DIPL & $\begin{array}{l}0.4455 \\
(2.98)\end{array}$ & 0.0090 & $\begin{array}{l}0.2219 \\
(8.19)\end{array}$ & 0.0567 \\
\hline $\mathrm{BACH}$ & $\begin{array}{l}0.1589 \\
(0.79)\end{array}$ & 0.0032 & $\begin{array}{l}0.1895 \\
(5.43)\end{array}$ & 0.0484 \\
\hline BACHPL & $\begin{array}{c}-0.1032 \\
(-0.37)\end{array}$ & -0.0021 & $\begin{array}{l}0.0184 \\
(0.39)\end{array}$ & 0.0047 \\
\hline PHD & $\begin{array}{c}-1.3889 \\
(-1.47)\end{array}$ & -0.0281 & $\begin{array}{c}-0.0581 \\
(-0.42)\end{array}$ & -0.0148 \\
\hline MAR & $\begin{array}{l}-0.2451 \\
(-1.41)\end{array}$ & -0.0050 & $\begin{array}{l}-0.0866 \\
(-2.75)\end{array}$ & -0.0221 \\
\hline MAR_CHL & $\begin{array}{c}-0.0452 \\
(-0.28)\end{array}$ & -0.0009 & $\begin{array}{l}0.0977 \\
(3.33)\end{array}$ & 0.0249 \\
\hline $\begin{array}{l}\text { LWDIF } \\
\text { CONSTANT }\end{array}$ & $\begin{array}{c}-2.4993 \\
(-29.28) \\
9.6482 \\
(21.17) \\
\end{array}$ & -0.0505 & $\begin{array}{c}0.6892 \\
(45.33) \\
0.4637 \\
(7.52) \\
\end{array}$ & 0.1759 \\
\hline $\begin{array}{l}\text { ESTRELLA } \\
\text { R-SQUARE }\end{array}$ & \multicolumn{2}{|c|}{0.9706} & \multicolumn{2}{|c|}{0.16022} \\
\hline $\begin{array}{l}\text { NORMALIZED SUCCESS } \\
\text { INDEX }\end{array}$ & \multicolumn{2}{|c|}{0.970} & \multicolumn{2}{|c|}{0.163} \\
\hline
\end{tabular}

Table A-5: Decomposition of wage differentials between naturalized citizens and permanent residents of Canada: population of foreign born employees 25-65 years old

\begin{tabular}{|c|c|l|c|}
\hline & $\begin{array}{l}\text { Naturalized citizens - } \\
\text { permanent residents } \\
\text { wage differential }\end{array}$ & $\begin{array}{l}\text { Difference } \\
\text { unexplained by human } \\
\text { capital endowments } \\
\text { (structural differences) }\end{array}$ & $\begin{array}{l}\text { Differences due to the } \\
\text { human capital } \\
\text { endowments }\end{array}$ \\
\hline All & $\mathbf{1 6 . 9 \%}$ & $5.8 \%$ & $11.1 \%$ \\
\hline Males & $\mathbf{1 4 . 9 \%}$ & $3 \%$ & $11.9 \%$ \\
\hline Females & $\mathbf{1 6 . 4 0 \%}$ & $9.20 \%$ & $7.20 \%$ \\
\hline OECD & $\mathbf{1 3 . 4 \%}$ & $5.5 \%$ & $7.9 \%$ \\
\hline Males & $\mathbf{1 1 . 2 \%}$ & $3.6 \%$ & $7.6 \%$ \\
\hline Females & $\mathbf{1 0 . 5 \%}$ & $7.8 \%$ & $2.7 \%$ \\
\hline NON-OECD & $\mathbf{3 3 \%}$ & $13.6 \%$ & $19.4 \%$ \\
\hline Males & $\mathbf{3 2 . 7 \%}$ & $12.9 \%$ & $19.8 \%$ \\
\hline Females & $\mathbf{3 2 . 9 \%}$ & $14.5 \%$ & $18.4 \%$ \\
\hline
\end{tabular}


Appendix B: Public Finance Regressions for OECD and Non-OECD Immigrants

Table B-1: OECD Immigrants: Total Transfers

a) Dependent Variable: TTLGOVRTRANSFRPAYMNT

\begin{tabular}{|l|l|r|r|r|r|r|}
\hline Model & & \multicolumn{2}{|c|}{$\begin{array}{c}\text { Unstandardized } \\
\text { Coefficients }\end{array}$} & \multicolumn{2}{c|}{$\begin{array}{c}\text { Standardized } \\
\text { Coefficients }\end{array}$} & \multicolumn{1}{c|}{$\mathrm{t}$} \\
\hline & & \multicolumn{1}{c|}{ B } & Std. Error & Beta & & \\
\hline 1 & (Constant) & -4581.730 & 105.690 & & -43.351 & .000 \\
& AGE & 200.508 & 1.400 & .580 & 143.219 & .000 \\
& LMARRIED & -2141.543 & 47.970 & -.171 & -44.643 & .000 \\
& CITIZ & -11.552 & 49.677 & -.001 & -.233 & .816 \\
& TOTAL INCOME & -.017 & .001 & -.078 & -21.434 & .000 \\
& HOUSEHOLD SIZE & 106.152 & 16.585 & .026 & 6.401 & .000 \\
\hline
\end{tabular}

Model Summary

\begin{tabular}{|c|c|c|c|c|}
\hline Model & $\mathrm{R}$ & R Square & $\begin{array}{l}\text { Adjusted R } \\
\text { Square }\end{array}$ & Std. Error of the Estimate \\
\hline 1 & $.593(a)$ & .351 & .351 & 4540.359 \\
\hline
\end{tabular}

a Predictors: (Constant), HOUSEHOLD SIZE, TOTAL INCOME, CITIZ, LMARRIED, AGE

\section{Table B-2: OECD Immigrants: Pension Transfers}

b) Dependent Variable: OAS PENSION GIS

\begin{tabular}{|r|l|r|r|r|r|r|}
\hline Model & & \multicolumn{2}{|c|}{$\begin{array}{c}\text { Unstandardized } \\
\text { Coefficients }\end{array}$} & $\begin{array}{c}\text { Standardized } \\
\text { Coefficients }\end{array}$ & \multicolumn{1}{c|}{$\mathrm{t}$} & Sig. \\
\hline & & \multicolumn{1}{|c|}{$\mathrm{B}$} & \multicolumn{1}{c|}{ Std. Error } & \multicolumn{1}{c|}{ Beta } & & \\
\hline 1 & (Constant) & -3708.680 & 43.479 & & -85.299 & .000 \\
& AGE & 122.042 & .576 & .717 & 211.902 & .000 \\
& LMARRIED & -1298.885 & 19.734 & -.211 & -65.819 & .000 \\
& CITIZ & -129.230 & 20.436 & -.020 & -6.324 & .000 \\
& TOTAL INCOME & -.012 & .000 & -.113 & -37.055 & .000 \\
& HOUSEHOLD SIZE & 37.773 & 6.823 & .019 & 5.536 & .000 \\
\hline
\end{tabular}

Model Summary

\begin{tabular}{|l|l|r|r|r|}
\hline Model & $\mathrm{R}$ & R Square & $\begin{array}{c}\text { Adjusted R } \\
\text { Square }\end{array}$ & \multicolumn{2}{c|}{ Std. Error of the Estimate } \\
\hline 1 & $.739(\mathrm{a})$ & .546 & .546 & \\
\hline
\end{tabular}

a Predictors: (Constant), HOUSEHOLD SIZE, TOTAL INCOME, CITIZ, LMARRIED, AGE 


\section{Table B-3:OECD Immigrants: Unemployment Benefits}

c) Dependent Variable: UI BENEFITS

\begin{tabular}{|l|l|r|r|r|r|r|}
\hline Model & & \multicolumn{2}{|c|}{$\begin{array}{c}\text { Unstandardized } \\
\text { Coefficients }\end{array}$} & $\begin{array}{c}\text { Standardized } \\
\text { Coefficients }\end{array}$ & \multicolumn{1}{c|}{$\mathrm{t}$} & Sig. \\
\hline & & \multicolumn{1}{c|}{$\mathrm{B}$} & \multicolumn{1}{c|}{ Std. Error } & Beta & & \\
\hline 1 & (Constant) & 1080.376 & 41.210 & & 26.217 & .000 \\
& AGE & -12.850 & .546 & -.118 & -23.540 & .000 \\
& LMARRIED & 98.440 & 18.704 & .025 & 5.263 & .000 \\
& CITIZ & 17.021 & 19.370 & .004 & .879 & .380 \\
& TOTAL INCOME & -.001 & .000 & -.013 & -2.934 & .003 \\
& HOUSEHOLD SIZE & -14.984 & 6.467 & -.012 & -2.317 & .020 \\
\hline
\end{tabular}

a Dependent Variable: UI BENEFITS

\begin{tabular}{|c|c|c|c|c|}
\hline \multicolumn{5}{|c|}{ Model Summary } \\
\hline Model & $\mathrm{R}$ & R Square & $\begin{array}{l}\text { Adjusted R } \\
\text { Square }\end{array}$ & Std. Error of the Estimate \\
\hline 1 & $.113(a)$ & .013 & .013 & 1770.338 \\
\hline
\end{tabular}

a Predictors: (Constant), HOUSEHOLD SIZE, TOTAL INCOME, CITIZ, LMARRIED, AGE

LOW FIT!

\section{Table B-4:Non-OECD Immigrants: Total Transfers}

a) Dependent Variable: TTLGOVRTRANSFRPAYMNT

\begin{tabular}{|l|l|r|r|r|r|r|}
\hline Model & & \multicolumn{2}{|c|}{$\begin{array}{c}\text { Unstandardized } \\
\text { Coefficients }\end{array}$} & $\begin{array}{c}\text { Standardized } \\
\text { Coefficients }\end{array}$ & \multicolumn{1}{c|}{$\mathrm{t}$} & Sig. \\
\hline & & \multicolumn{1}{|c|}{$\mathrm{B}$} & \multicolumn{1}{c|}{ Std. Error } & \multicolumn{1}{c|}{ Beta } & & \\
\hline 1 & & -1445.325 & 104.139 & & -13.879 & .000 \\
& AGE & 135.107 & 1.423 & .480 & 94.933 & .000 \\
& LMARRIED & -1276.878 & 52.603 & -.118 & -24.274 & .000 \\
& CITIZ & 517.295 & 54.205 & .047 & 9.543 & .000 \\
& TOTAL INCOME & -.003 & .001 & -.011 & -2.347 & .019 \\
& HOUSEHOLD SIZE & -219.868 & 14.358 & -.076 & -15.313 & .000 \\
\hline
\end{tabular}

\begin{tabular}{|c|c|c|c|c|}
\hline \multicolumn{5}{|c|}{ Model Summary } \\
\hline Model & $\mathrm{R}$ & R Square & $\begin{array}{l}\text { Adjusted R } \\
\text { Square }\end{array}$ & Std. Error of the Estimate \\
\hline 1 & $.518(a)$ & .269 & .269 & 4285.853 \\
\hline
\end{tabular}

a Predictors: (Constant), HOUSEHOLD SIZE, TOTAL INCOME, LMARRIED, CITIZ, AGE 


\section{Table B-5: Non-OECD Immigrants: Pension Transfers}

b) Dependent Variable: OAS PENSION GIS

\begin{tabular}{|c|c|c|c|c|c|c|}
\hline Model & & \multicolumn{2}{|c|}{$\begin{array}{c}\text { Unstandardized } \\
\text { Coefficients }\end{array}$} & \multirow{2}{*}{$\begin{array}{c}\text { Standardized } \\
\text { Coefficients } \\
\text { Beta }\end{array}$} & \multirow[t]{2}{*}{$\mathrm{t}$} & \multirow[t]{2}{*}{ Sig. } \\
\hline & & $\mathrm{B}$ & Std. Error & & & \\
\hline \multirow[t]{6}{*}{1} & (Constant) & -1997.320 & 45.129 & & -44.258 & .000 \\
\hline & AGE & 89.514 & .617 & .630 & 145.141 & .000 \\
\hline & LMARRIED & -1108.122 & 22.796 & -.203 & -48.611 & .000 \\
\hline & CITIZ & 352.108 & 23.490 & .064 & 14.990 & .000 \\
\hline & TOTAL INCOME & -.010 & .001 & -.082 & -19.531 & .000 \\
\hline & HOUSEHOLD SIZE & -112.868 & 6.222 & -.078 & -18.140 & .000 \\
\hline
\end{tabular}

Model Summary

\begin{tabular}{|l|l|r|r|rr|}
\hline Model & $\mathrm{R}$ & R Square & $\begin{array}{c}\text { Adjusted } \mathrm{R} \\
\text { Square }\end{array}$ & \multicolumn{2}{|c|}{ Std. Error of the Estimate } \\
\hline 1 & $.679(\mathrm{a})$ & .461 & .461 & & 1857.293 \\
\hline
\end{tabular}

a Predictors: (Constant), HOUSEHOLD SIZE, TOTAL INCOME, LMARRIED, CITIZ, AGE

Table B-6: Non-OECD Immigrants: UI Benefits

c) Dependent Variable: UI BENEFITS

\begin{tabular}{|l|l|r|r|r|r|r|}
\hline Model & & \multicolumn{2}{|c|}{$\begin{array}{c}\text { Unstandardized } \\
\text { Coefficients }\end{array}$} & $\begin{array}{c}\text { Standardized } \\
\text { Coefficients }\end{array}$ & \multicolumn{1}{c|}{$\mathrm{t}$} & Sig. \\
\hline & & \multicolumn{1}{c|}{$\mathrm{B}$} & Std. Error & Beta & & \\
\hline 1 & (Constant) & 767.451 & 43.073 & & 17.818 & .000 \\
& AGE & -10.164 & .589 & -.101 & -17.268 & .000 \\
& LMARRIED & 230.358 & 21.757 & .060 & 10.588 & .000 \\
& CITIZ & -6.083 & 22.420 & -.002 & -.271 & .786 \\
& TOTAL INCOME & .002 & .000 & .025 & 4.421 & .000 \\
& HOUSEHOLD SIZE & -8.571 & 5.939 & -.008 & -1.443 & .149 \\
\hline
\end{tabular}

Model Summary

\begin{tabular}{|l|l|r|r|rr|}
\hline Model & $\mathrm{R}$ & R Square & $\begin{array}{c}\text { Adjusted } \mathrm{R} \\
\text { Square }\end{array}$ & \multicolumn{2}{|c|}{ Std. Error of the Estimate } \\
\hline 1 & $.111(\mathrm{a})$ & $\mathbf{0 1 2}$ & $\mathbf{0 1 1 2}$ & & 1772.664 \\
\hline
\end{tabular}

a Predictors: (Constant), HOUSEHOLD SIZE, TOTAL INCOME, LMARRIED, CITIZ, AGE 


\section{Appendix C: Calculation of total taxes}

age $>14$ and age $<76$

Calculation of income tax (Census of Canada 1996):

if totincp $<6,457 \quad$ then inctax $=0$

if totincp $<29,591$ and totincp $>6,456$ then inctax $=.17 *$ totincp-chdbnp

if totincp $>29,590$ and totincp $<59,181$ then inctax $=5,030+.26^{*}$ (totincp-29,590)-chdbnp

if totincp $>59,180$ then

inctax $=12,724+.29 *($ totincp-59,180)-chdbnp

where totincp - total income, chbnp - child benefits.

Calculation of Average Propensity to Consume (FAMEX 1995):

$\mathrm{APC}=($ total current consumption- rent- food from stores- health care- child care)/household income after taxes

\begin{tabular}{|c|c|}
\hline & $\begin{array}{c}\text { Average } \\
\text { Propensity to } \\
\text { Consume }\end{array}$ \\
\cline { 2 - 2 } & Mean \\
\hline age 15-24 & .98 \\
age 25-34 & .85 \\
age 35-44 & .74 \\
age 45-54 & .70 \\
age 55-64 & .73 \\
age 65-75 & .63 \\
\hline
\end{tabular}

Calculation of Total Taxes (Census of Canada 1996):

Salestax $=.14 *$ APC $*($ totincp-inctax $)$

$\mathrm{GST}=.07 * \mathrm{APC} *($ totincp-inctax $)$

Totfedtax $=$ inctax + GST

Tottaxes $=$ inctax + salestax 